\title{
A mobile sensor network to map carbon dioxide emissions in urban environments
}

\author{
Joseph K. Lee ${ }^{1}$, Andreas Christen ${ }^{1}$, Rick Ketler ${ }^{1}$, and Zoran Nesic ${ }^{1,2}$ \\ ${ }^{1}$ Department of Geography/Atmospheric Science Program, University of British Columbia, Vancouver, BC, Canada \\ ${ }^{2}$ Biometeorology Group, Faculty of Land and Food Systems, University of British Columbia, Vancouver, BC, Canada \\ Correspondence to: Andreas Christen (andreas.christen@ubc.ca)
}

Received: 9 June 2016 - Discussion started: 20 June 2016

Revised: 26 January 2017 - Accepted: 1 February 2017 - Published: 1 March 2017

\begin{abstract}
A method for directly measuring carbon dioxide $\left(\mathrm{CO}_{2}\right)$ emissions using a mobile sensor network in cities at fine spatial resolution was developed and tested. First, a compact, mobile system was built using an infrared gas analyzer combined with open-source hardware to control, georeference, and $\log$ measurements of $\mathrm{CO}_{2}$ mixing ratios on vehicles (car, bicycles). Second, two measurement campaigns, one in summer and one in winter (heating season) were carried out. Five mobile sensors were deployed within a $1 \times$ $12.7 \mathrm{~km}$ transect across the city of Vancouver, BC, Canada. The sensors were operated for $3.5 \mathrm{~h}$ on pre-defined routes to map $\mathrm{CO}_{2}$ mixing ratios at street level, which were then averaged to $100 \times 100 \mathrm{~m}$ grid cells. The averaged $\mathrm{CO}_{2}$ mixing ratios of all grids in the study area were $417.9 \mathrm{ppm}$ in summer and $442.5 \mathrm{ppm}$ in winter. In both campaigns, mixing ratios were highest in the grid cells of the downtown core and along arterial roads and lowest in parks and well vegetated residential areas. Third, an aerodynamic resistance approach to calculating emissions was used to derive $\mathrm{CO}_{2}$ emissions from the gridded $\mathrm{CO}_{2}$ mixing ratio measurements in conjunction with mixing ratios and fluxes collected from a $28 \mathrm{~m}$ tall eddycovariance tower located within the study area. These measured emissions showed a range of -12 to $226 \mathrm{CO}_{2} \mathrm{ha}^{-1} \mathrm{~h}^{-1}$ in summer and of -14 to $163 \mathrm{~kg} \mathrm{CO}_{2} \mathrm{ha}^{-1} \mathrm{~h}^{-1}$ in winter, with an average of $35.1 \mathrm{~kg} \mathrm{CO}_{2} \mathrm{ha}^{-1} \mathrm{~h}^{-1}$ (summer) and $25.9 \mathrm{~kg} \mathrm{CO}_{2} \mathrm{ha}^{-1} \mathrm{~h}^{-1}$ (winter). Fourth, an independent emissions inventory was developed for the study area using buildings energy simulations from a previous study and routinely available traffic counts. The emissions inventory for the same area averaged to $22.06 \mathrm{~kg} \mathrm{CO}_{2} \mathrm{ha}^{-1} \mathrm{~h}^{-1}$ (summer) and $28.76 \mathrm{~kg} \mathrm{CO}_{2} \mathrm{ha}^{-1} \mathrm{~h}^{-1}$ (winter) and was used to compare against the measured emissions from the mobile sensor
\end{abstract}

network. The comparison on a grid-by-grid basis showed linearity between $\mathrm{CO}_{2}$ mixing ratios and the emissions inventory $\left(R^{2}=0.53\right.$ in summer and $R^{2}=0.47$ in winter). Also, $87 \%$ (summer) and $94 \%$ (winter) of measured grid cells show a difference within \pm 1 order of magnitude, and $49 \%$ (summer) and $69 \%$ (winter) show an error of less than a factor 2. Although associated with considerable errors at the individual grid cell level, the study demonstrates a promising method of using a network of mobile sensors and an aerodynamic resistance approach to rapidly map greenhouse gases at high spatial resolution across cities. The method could be improved by longer measurements and a refined calculation of the aerodynamic resistance.

\section{Introduction}

Cities and the cumulative processes of urbanization are key drivers of local and global environmental change (Mills, 2007; Grimmond, 2007). As cities are the centres of increasing population growth and resource consumption, they are also the dominant source of greenhouse gas emissions - in particular carbon dioxide $\left(\mathrm{CO}_{2}\right)$ - into the atmosphere (Rosenzweig et al., 2010). On the global scale, urban areas are responsible for up to $80 \%$ of the total anthropogenic $\mathrm{CO}_{2}$ emissions footprint (Satterthwaite, 2008). Cities are thus responsible for a major proportion of the anthropogenic greenhouse gas emissions that are intensifying positive atmospheric radiative forcing of the troposphere contributing to global climate change (IPCC, 2013), although a large fraction of the emissions related to the resource chains that sus- 
tain cities does not occur within the built-up area but rather is emitted elsewhere.

Within cities, the major sources of $\mathrm{CO}_{2}$ are the combustion of fossil fuels for heating, ventilation, and cooling systems (HVAC), transportation, industrial processes, and power generation (Kennedy et al., 2009). These fossil fuel emissions are combined with $\mathrm{CO}_{2}$ emitted from biological sources, namely soil, plant, and human respiration, and in part taken up by photosynthesis of urban vegetation (Christen et al., 2011). Overall, fossil fuel sources dominate $\mathrm{CO}_{2}$ fluxes in cities. The sequestration of $\mathrm{CO}_{2}$ by urban vegetation in most cities is very limited (Velasco et al., 2016). However, the rate of $\mathrm{CO}_{2}$ uptake by photosynthesis at a given time can be relevant and is measurable in highly vegetated cities during the daytime in the growing season (Peters and McFadden, 2012; Weissert et al., 2014). The dominance of fuel emissions results in increased concentrations of $\mathrm{CO}_{2}$ in the urban boundary layer (UBL) relative to rural or pristine air (Idso et al., 2001; Grimmond et al., 2002; Vogt et al., 2006). The enrichment of $\mathrm{CO}_{2}$ in the UBL links directly to emissions which are controlled by urban form and function.

With more than $50 \%$ of the global population now living in cities (United Nations, 2014), cities are also the place where effective mitigation of climate change, driven by policy, design, and bottom-up citizen engagement is possible. According to IPCC (2014), the urban scale has the highest potential for fast, efficient, and sustained implementation of mitigation efforts. Central to the reduction of urban $\mathrm{CO}_{2}$ emissions is the availability of reliable emissions information and inventories and methods of validating city-scale emissions estimates and reduction efforts. While there are a growing number of methods of quantifying emissions in urban areas, there are disconnects between the current spatial and temporal resolution of emissions models, the ever-evolving urban form and function, and block to neighbourhood-scale measurements which inform and validate emissions models (Pataki et al., 2009; Kellett et al., 2013). It further remains a challenge to directly measure emissions at fine urban scales and separate $\mathrm{CO}_{2}$ emission measurements in the urban atmosphere into different fossil fuel emissions and biological sources (Christen, 2014).

The research goal of this study is to develop, apply, and test a new methodology to map $\mathrm{CO}_{2}$ emissions in complex urban environments. Data from a network of mobile sensors and an eddy-covariance flux tower combined with an aerodynamic approach are used to calculate and map emissions at fine scales (blocks to neighbourhoods) in cities.

Mobile measurements have been used in the past for studying and mapping the spatial variability of greenhouse gases in cities (Jimenez et al., 2000; Idso et al., 2001; Henninger and Kuttler, 2007; Crawford and Christen, 2014). Because trace gas analyzer systems for greenhouse gases are still bulky (e.g. Tao et al., 2015), past mobile mapping studies utilized specialized research vehicles (Bukowiecki et al., 2002; Elen et al., 2013; Crawford and Christen, 2014). While these ve- hicles have the advantage that they can be equipped with additional components such as calibration tanks or computers, the complexity of such systems does not allow for easy deployment on standard and flexible modes of transport.

There is increasing interest to develop innovative methods for monitoring urban climate and air pollution using lowcost distributed sensor networks. For example, Meier et al. (2017) used sensor data from a commercial consumer-grade weather station network to examine fine-scale urban heat island effects in the city of Berlin. In another example, Chapman et al. (2014) developed a road sensor network to monitor road surface temperatures to optimally salt roads during the winter months in Birmingham. Given this growing interest in distributed sensing systems and the advances in the related technologies, could there be new opportunities for the fine-scale mapping of $\mathrm{CO}_{2}$ emissions in cities? This study investigates whether it is feasible to map greenhouse gas emissions, specifically $\mathrm{CO}_{2}$, at a spatial resolution of neighbourhoods/blocks across the city with a portable network of mobile sensors that can be routinely implemented on various mobile platforms. In order to address this question, four major objectives were pursued.

1. Sensor development: develop and test a compact, mobile, and multi-modal $\mathrm{CO}_{2}$ sensor for bicycles and cars.

2. Measurement campaign: deploy the sensors in a targeted measurement campaign.

3. Methodology development: calculate emissions from measurements of $\mathrm{CO}_{2}$ mixing ratios and aerodynamic resistance (in the following called "measured emissions").

4. Analysis and evaluation: compare the measured emissions to fine-scale traffic and building emissions inventories. Can we find agreement between the spatial patterns in the inventories and measured emissions?

\section{Methods}

\subsection{The mobile measurement system for carbon dioxide}

A mobile $\mathrm{CO}_{2}$ monitoring system was required to address the project's need for multiple, low-cost yet accurate sensors capable of measuring mixing ratios and position at high frequency $(\approx 1 \mathrm{~Hz}$ to have an error of $5 \mathrm{~m}$ at typical driving speeds) and easily deployable on bicycles and passenger cars with a compact design. A mobile monitoring system with such specifications is necessary to cover large geographic areas within limited timescales at sufficiently fine resolution that are representative of typical urban emission patterns. With typical vehicle speed and a characteristic urban street layout/traffic density, one sensor is capable of covering between 0.5 and $1 \mathrm{~km}^{2} \mathrm{~h}^{-1}$. Sensor systems with many 
of these specifications do already exist, but few, if any, were designed to be carried on and easily interface with various types of mobile platforms; all studies using high accuracy $\mathrm{CO}_{2}$ sensors have been either stationary or mounted in specialized vehicles because of the weight, power consumption, size, and high cost of the sensors being used.

\subsubsection{System design}

We used a commercially available carbon dioxide infrared analyzer (IRGA) (Li-820, Licor Inc., Lincoln, NE, USA). The Li-820 is a compact $(23.23 \times 15.25 \times 7.62 \mathrm{~cm}, 1 \mathrm{~kg})$, low maintenance (approx. 2 years of continuous use), and low noise ( $\pm 1 \mathrm{ppm}) \mathrm{CO}_{2}$ analyzer (Li-Cor, 2015). The Li820 uses a single path infrared light to determine the $\mathrm{CO}_{2}$ mixing ratio within a closed path by detecting the amount of absorption of the light from the path. The Li-820 was operated with a nominal sampling rate (data output) of $1 \mathrm{~Hz}$ but the actual time constant of the system was determined to be $3.2 \mathrm{~s}$ (see Appendix A2). The gas analyzer was coupled with an Arduino microcontroller (Arduino CC, Ivrea, Italy). The Arduino platform is capable of communicating digitally with the IRGA, a Global Positioning System (GPS) unit (Adafruit Ultimate GPS Logger Shield with GPS Module, Manhattan, New York, USA) unit, and a digital temperature thermometer (Maxim Integrated One Wire Digital Temperature Sensor - DS18B20, San Jose, CA, USA). A custom hardware board was developed to connect all of the components together to distribute the correct amount of power to each of the hardware components and to allow for compact hardware and sensor input. The portable $\mathrm{CO}_{2}$ system was named the "DoIt-Yourself-Sensor- $\mathrm{CO}_{2}$ ”, or "DIYSCO ${ }_{2}$ " system (Fig. 1a)

The DIYSCO 2 system reports $\mathrm{CO}_{2}$ as mixing ratios $(r)$ in ppm, geoposition (latitude/longitude, speed, altitude, and satellite strength), and internal and external air temperature which are logged onto a micro secure digital (microSD) card at $1 \mathrm{~s}$ intervals. Air is drawn into the DIYSCO system through a $3 \mathrm{~m}$ long inlet tube $(6.35 \mathrm{~mm}$ diameter, Synflex, polyethylene-aluminum composite, Eaton, Eden Prairie, MN, USA) using a small KNF NMP015 microdiaphragm pump (KNF Neuberger, Inc., Trenton, NJ, USA), first passing through a mesh filter at the sample inlet head to prevent large particles from entering the $\mathrm{DIYSCO}_{2}$ system (e.g. insects) and then through a Balston disposable filter unit (DFU) (Parker Hannifin Corporation, Lancaster, NY, USA) at the end of the $3 \mathrm{~m}$ tube. The flow rate is regulated by a Swagelok needle valve at $700 \mathrm{cc} \mathrm{min}^{-1}$ as recommended by Licor to minimize the effect of internal cell pressure changes on the $\mathrm{CO}_{2}$ measurements. The entire DIYSCO system is $35.8 \mathrm{~cm} \times 27.8 \mathrm{~cm} \times 11.8 \mathrm{~cm}$, weighs $2.6 \mathrm{~kg}$, and is contained in a weather-proof case (NANUK 910, Plasticase, Terrebonne, CA, USA). The system is powered by a single 9-18V DC/DC input which can be supplied by battery or via car cigarette lighter socket.
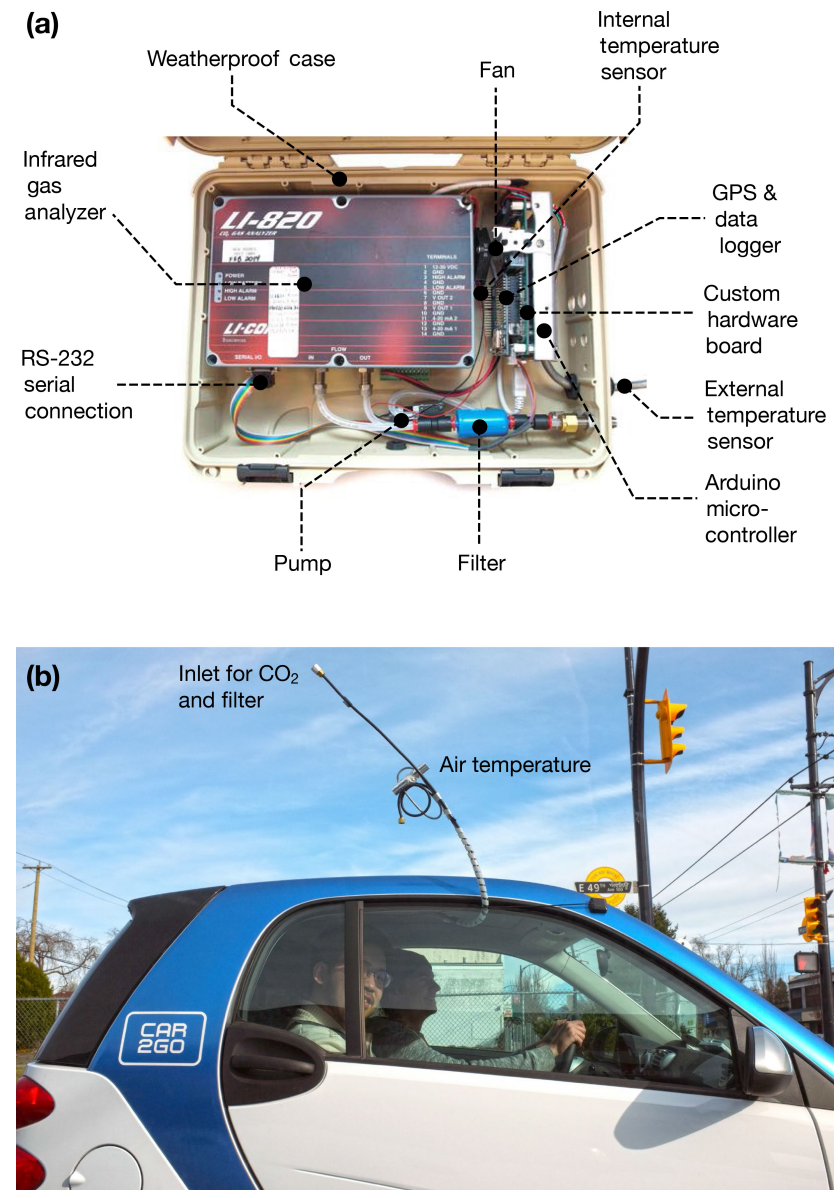

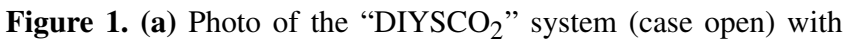
components labelled. (b) The inlet is mounted through the passenger window (right side) of the vehicle; the "DIYSCO 2 " sits in the trunk space.

\subsubsection{System testing and installation}

Within the range of typical ambient mixing ratios of $\mathrm{CO}_{2}$ between 400 and $550 \mathrm{ppm}$ the $\mathrm{DIYSCO}_{2}$ system showed strong linearity ( $R^{2}$ of 0.9999$)$ and a root mean square error (RMSE) of $0.233 \mathrm{ppm}$ relative to four different mixing ratios (six tanks) of reference gases (see Appendix A1). The maximum sensor drift over $3 \mathrm{~h}$ (the duration of the campaign, see below) under controlled conditions was in the range of -0.31 and $+0.51 \mathrm{ppm}$ (see Appendix A2). In the configuration used, the DIYSCO $\mathrm{SC}_{2}$ had a time lag of $18.2 \mathrm{~s}$ between measurement intake and analysis (see Appendix A3).

Appendix A4 discusses errors associated with mounting the inlet at different positions on the car which can lead to a systematic bias. Generally, values on the driver side (centre of road) were higher than the passenger side. In the current work, the sample inlet tube was run out through the passenger side window of the vehicle. The sampling line inlet was $70 \mathrm{~cm}$ over the vehicle's roof and $2.2 \mathrm{~m}$ above the road sur- 
face (Fig. 1b). In order to deploy the DIYSCO 2 on a bicycle, the setup requires a $40 \mathrm{~L}$ backpack to carry the sensor and a 7 amp-hour, $12 \mathrm{~V}$ gel-cell battery and a $1.5 \mathrm{~m}$ long rigid mounting tube $(6 \mathrm{~mm}$ diameter) to mount the inlet tube above the cyclist. The sensor is placed in the backpack with the battery and worn on the back of the cyclist to reduce vibrations to the sensor system.

\subsection{Measurement campaigns}

The systems were tested in two field campaigns. In each of the campaigns, a fleet of five sensors was operated simultaneously on pre-defined routes to evaluate the potential to map emissions and compare them against inventory data.

\subsubsection{Study area}

The study area is a $12.7 \mathrm{~km} \times 1 \mathrm{~km}$ quadrangle within the city of Vancouver, BC, which spans from the northern-most tip of the city in forested "Stanley Park" $\left(49^{\circ} 18^{\prime} 45.17^{\prime \prime} \mathrm{N}\right.$, $123^{\circ} 09^{\prime} 29.10^{\prime \prime} \mathrm{W}$, WGS-84) to the city's south eastern neighbourhood "Victoria - Fraserview" $\left(49^{\circ} 12^{\prime} 59.00^{\prime \prime} \mathrm{N}\right.$, $123^{\circ} 03^{\prime} 46.90^{\prime \prime} \mathrm{W}$ ) (Fig. 2). It includes dominant urban land uses - the downtown core, medium density residential, single detached residential, light industrial development, parks, and forest. The study area encompasses approximately $11.1 \%$ of the total area of the city of Vancouver and was selected because of the provision of high-resolution geospatial data, including light detection and ranging (lidar) measurements of urban form used for building emission simulations in previous research (van der Laan, 2011), the availability of detailed traffic counts, and the location of a $30 \mathrm{~m}$ tall eddy-covariance tower.

\subsubsection{Flux tower measurements}

The eddy-covariance flux tower "Vancouver-Sunset" (ID: Ca-VSu, FLUXNET, 2016; Crawford and Christen, 2015) is located near the south east corner of the study area $\left(49^{\circ} 13^{\prime} 34.0^{\prime \prime} \mathrm{N}, 123^{\circ} 04^{\prime} 42.2^{\prime \prime} \mathrm{W}\right)$. On the flux tower, a CSAT-3 ultrasonic anemometer-thermometer (Campbell Scientific Inc., Logan, UT, USA) measured continuously sensible heat flux $(H)$, wind direction, and wind velocity. Further, air temperature $\left(T_{\text {tower }}\right)$ was measured with a shielded HMP 45 thermometer/hygrometer (Vaisala Inc., Vanta, Finland). All four radiation components, including long-wave upwelling radiation $\left(L_{\uparrow}\right)$, were measured by a CNR-1 net radiometer (Kipp \& Zonen, Delft, the Netherlands). Carbon dioxide molar mixing ratios $r_{\text {tower }}$ were measured near tower top $(28 \mathrm{~m})$ using a tube that pumps air to a TGA200 closed path analyzer (Campbell Scientific Inc.). In addition, $\mathrm{CO}_{2}$ mixing ratios were measured by a Licor-7500 open path IRGA (Licor Inc., Lincoln, NE, USA) co-located with the ultrasonic anemometer-thermometer. The TGA200 was calibrated every $10 \mathrm{~min}$ against three WMO-traceable tanks of known $\mathrm{CO}_{2}$ mixing ratios to ensure an accuracy of

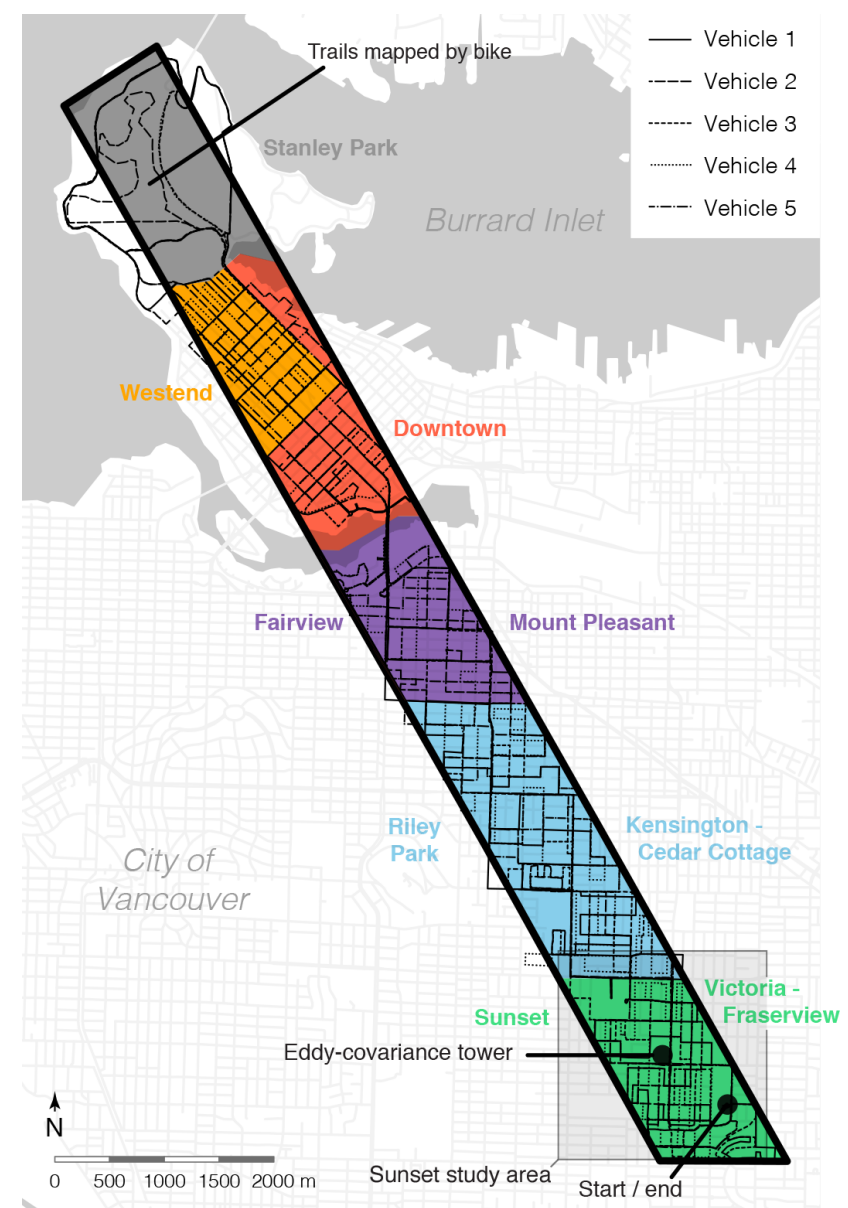

Figure 2. Map of the study area (thick black outline). Thin black lines refer to the paths of each of the five $\mathrm{DIYSCO}_{2}$ systems. The coloured areas are the neighbourhoods used in further analysis. The location of the eddy-covariance tower and the start and end point of all paths are labelled. The $1.9 \times 1.9 \mathrm{~km}$ box labelled "Sunset study area" refers to the domain of previous research, including the finescale emission inventory developed by Christen et al. (2011) and Kellett et al. (2013).

$<0.15 \mathrm{ppm}$. The Licor-7500 is calibrated twice a year in the lab. Further details of the site location, instrument exposure, and data processing are discussed in Crawford and Christen (2015). Measurements on the flux tower made it possible to link mobile measurements with data from above the city and determine aerodynamic resistances for the calculation of emissions (see Sect. 2.3.2)

\subsubsection{Mobile measurements}

Two field campaigns took place, the first on 28 May 2015 (non-heating season, broadleaf vegetation with leaves emerged) and the second on 18 March 2016 (heating season, before leaf emergence). For simplicity, datasets from the two dates will be referred to as "summer" (28 May 2015) and "winter" (18 March 2016). Sampling was conducted from 
10:00 to 13:30 LT (Pacific Time), when vehicular traffic and meteorological conditions are relatively constant.

Five DIYSCO ${ }_{2}$ systems were installed on vehicles. Each of the five vehicles was assigned a route to travel approximately $70 \mathrm{~km}$ during the study period (achieving an optimal sampling density of about $3.5 \mathrm{~km}^{2} \mathrm{~h}^{-1}$ ). Each vehicle started and ended at the southeast corner of the transect $\left(49^{\circ} 13^{\prime} 15.08^{\prime \prime} \mathrm{N}, 123^{\circ} 04^{\prime} 14.11^{\prime \prime} \mathrm{W}\right.$; Fig. 2). The routes of the five systems were drawn such that a majority of the streets and lanes in the study area would be sampled at least once in the $3.5 \mathrm{~h}$ time period, but ideally sampled at different times throughout the campaign. The routes were evaluated using an overlaid $100 \times 100 \mathrm{~m}$ grid, confirming that nearly all of the grid cells would be crossed by at least one system if the routes were successfully completed. Furthermore, a bicycle was used to traverse trails in the forested area of "Stanley Park" to sample along pathways in the densely forested ecosystem away from roads.

Prior to the mobile measurements, all vehicles were parked on the southeastern corner of Gordon Park, away from major streets in a school parking lot. The five $\mathrm{DIYSCO}_{2}$ systems were operated for a $15 \mathrm{~min}$ warm-up period in their respective vehicles parked next to each other and then logged for $5 \mathrm{~min}$ in order to determine their relative offsets before the field campaign; this is called the "in situ comparison". During the test, all people moved away and $30 \mathrm{~m}$ downwind of the vehicles to avoid contamination from human exhaust and all engines were turned off. After the $3.5 \mathrm{~h}$ traverse, all vehicles returned to the starting location, where a second in situ comparison was performed. The data collected in the in situ comparison were used to determine offsets and drift of the sensors during the campaign. The slope of the senors was determined in the lab the day before each campaign using two reference tanks.

\subsection{Data analysis}

\subsubsection{Data post-processing and gridding}

The $1 \mathrm{~Hz}$ data from all five $\mathrm{DIYSCO}_{2}$ systems were filtered according to Crawford and Christen (2014), so that all data were removed when the GPS recorded speeds were below $5 \mathrm{~km} \mathrm{~h}^{-1}$ (to avoid self contamination by vehicle exhaust when idling). Data were also removed where the IRGA cell temperature and pressure were below $45^{\circ} \mathrm{C}$ and $96 \mathrm{kPa}$, to measure within the specifications and calibration of the Li820.

Vector matrix grids of $50 \times 50 \mathrm{~m}, 100 \times 100 \mathrm{~m}$, $200 \times 200 \mathrm{~m}$, and $400 \times 400 \mathrm{~m}$ were mapped onto the study area in a Geographic Information System to spatially aggregate and attribute the $r_{\text {mobile }}$ measured by the $\mathrm{DIYSCO}_{2}$ systems to square grid cells. The separate data analysis for the $50,100,200$, and $400 \mathrm{~m}$ grids provided a way to determine the effects of grid size on emissions estimates. In the results section, the $100 \mathrm{~m}$ grid is selected because the
$100 \mathrm{~m}$ grid cell size was determined to be significantly large enough to avoid most micro-scale horizontal advection of emissions while also still attributing emissions at a traceable scale to individual arterial roads and features. Appendix C explores the effect of using different grid sizes by comparing the results from the $100 \mathrm{~m}$ grid to the 50,200 , and $400 \mathrm{~m}$ grids.

For each cell, the summary statistics were computed for all valid data points intersecting it. The summary statistics included the mean, median, maximum, minimum, range, skewness, and variance. The gridded data were also classified by neighbourhood (Fig. 2) to enable comparisons of $r_{\text {mobile }}$ for areas of different urban form and density. Only grid cells with actual measurements were retained for the analysis. All of the grid cells that did not fall "completely within" the boundaries of the study area were withheld from the analysis.

\subsubsection{Emission calculation and comparison}

Data from the eddy-covariance tower are used in conjunction with the gridded averages of $r_{\text {mobile }}$ to calculate emissions for each grid cell based on the aerodynamic resistance approach, which posits that the molar flux of $\mathrm{CO}_{2}$ for a given area and time $\left(\overline{w^{\prime} c^{\prime}}\right.$ in $\left.\mu \mathrm{mol} \mathrm{m}{ }^{-2} \mathrm{~s}^{-1}\right)$ is equal to the difference of the molar concentration $c$ (in $\mu \mathrm{mol} \mathrm{\textrm {m } ^ { - 3 }}$ ) at the height above the roughness sublayer $\left(c_{\text {tower }}\right)$ and screen level at $2 \mathrm{~m}$ height $\left(c_{\text {mobile }}\right)$ divided by the aerodynamic resistance of $\mathrm{CO}_{2}$ (in $\left.\mathrm{s} \mathrm{m}^{-1}\right)$ :

$\overline{w^{\prime} c^{\prime}}=-\frac{c_{\text {tower }}-c_{\text {mobile }}}{r_{\mathrm{aC}}}$.

While both $c_{\text {tower }}$ and $c_{\text {mobile }}$ are available through the measurement of $r$ and density (considering pressure and air temperature), the challenge is that $r_{\mathrm{aC}}$ cannot be directly and easily measured due to the spatial heterogeneity of $\overline{w^{\prime} c^{\prime}}$ and $c_{\text {mobile }}$. Hence, to make the approach more robust, it uses the availability of sensible heat flux $H\left(\mathrm{~W} \mathrm{~m}^{-2}\right)$, air temperature at $24 \mathrm{~m}$ height $\left(T_{\mathrm{a}}\right)$, and surface brightness temperatures $\left(T_{0}\right)$. This is possible because a city is a relatively homogeneous source of sensible heat and temperatures are more uniform than $\mathrm{CO}_{2}$ fluxes and mixing ratios. From the tower measurements of air temperature $\left(T_{\mathrm{a}}\right)$ and surface brightness temperature we then calculate the aerodynamic resistance of sensible heat $r_{\mathrm{aH}}$ (Kanda et al., 2007). $r_{\mathrm{aH}}$ is the integral resistance from the surface (ground, roofs) to the top of the tower.

$r_{\mathrm{aH}}=\rho c_{p} \frac{T_{\text {tower }}-T_{0}}{H}$,

where $T_{\text {tower }}$ is the air temperature $(\mathrm{K})$ at the height of the tower $(24 \mathrm{~m}), T_{0}$ is the surface brightness temperature (in $\mathrm{K}$, calculated as $T_{0}=\left(L_{\downarrow} / \sigma\right)^{0.25}$ ) from the longwave radiometer, where $\sigma=5.6 \times 10^{-8} \mathrm{~W} \mathrm{~m}^{-2} \mathrm{~K}^{-4}$ is the Stefan-Boltzmann constant), and $H$ is the sensible heat flux $\left(\mathrm{W} \mathrm{m}^{-2}\right)$ measured by eddy covariance. 
In a next step we assume Reynolds analogy (Arya, 2001) between heat and passive scalar transfer, i.e. that the aerodynamic resistance of sensible heat is equal to the aerodynamic resistance of carbon dioxide $\left(r_{\mathrm{aC}}\right)$ and rewrite Eq. (1).

In order to convert the molar flux $\overline{w^{\prime} c^{\prime}}$ (in $\mu \mathrm{mol} \mathrm{m}^{-2} \mathrm{~s}^{-1}$ ) to a mass flux $F_{c}$ consistent with inventories (in $\mathrm{kg} \mathrm{CO}_{2} \mathrm{ha}^{-1} \mathrm{~h}^{-1}$ ), we rewrite

$F_{c}=-M_{c} b_{a} b_{t} b_{o} b_{m} \frac{c_{\text {tower }}-c_{\text {mobile }}}{r_{\mathrm{aH}}}$,

where $M_{c}$ is the molar mass of $\mathrm{CO}_{2}\left(44.01 \mathrm{~g} \mathrm{~mol}^{-1}\right), b_{a}$ is a factor for converting $\mathrm{m}^{-2}$ to ha ${ }^{-1}$ (i.e. $b_{a}=10^{4} \mathrm{~m}^{2} \mathrm{ha}^{-1}$ ), $b_{t}$ is a factor for converting s $\mathrm{s}^{-1}$ to $\mathrm{h}^{-1}$ (i.e. $b_{t}=3600 \mathrm{~s} \mathrm{~h}^{-1}$ ), $b_{o}$ is the factor for converting $\mu \mathrm{mol}$ to mol (i.e. $b_{m}=$ $10^{-6} \mu \mathrm{mol}_{\mu \mathrm{mol}^{-1}}$ ), and $b_{m}$ is the factor for converting $\mathrm{g}$ to $\mathrm{kg}$ (i.e. $b_{m}=10^{-3} \mathrm{~kg} \mathrm{~g}^{-1}$ ).

Equation (3) was applied to each grid cell, where $c_{\text {mobile }}$ varied for each grid cell and each time while $r_{\mathrm{aH}}$ and $c_{\text {tower }}$ varied only over time. The calculated emissions $F_{c}$ are then compared to independent gridded building and traffic emissions estimates to test the feasibility and accuracy of the method (the derivation of the independent emissions inventories is documented in Appendix B).

In summary, this procedure to calculate emissions from mobile and tower measurements is only valid under the following key assumptions:

1. $\mathrm{CO}_{2}$ concentrations in the well-mixed UBL (the tower location) at daytime will not change dramatically over a short time period or space (e.g. over $30 \mathrm{~min}$ time periods are long enough where urban fluxes are well represented) given the same meteorological conditions and are therefore in an equilibrium. In other words, the measurements of $c_{\text {tower }}$ are representative of the UBL above each grid cell at any time.

2. The flux at the height of the tower is directly related to the flux at the surface; hence concentration changes over time in the layer between surface and tower are negligible at day (i.e. no storage flux). This assumption is supported by a previous study in which no storage flux was observed during daytime for this particular site (Crawford and Christen, 2014). However, this assumption is severely violated at night and in the early to mid morning (Crawford and Christen, 2014; Bjorkegren et al., 2015), so the proposed approach does only work midday or afternoon.

3. Reynolds analogy applies to $r_{\mathrm{aC}}=r_{\mathrm{aH}}$ and $r_{\mathrm{aH}}$ and therefore $r_{\mathrm{aC}}$ is constant across all the urban densities/local climate zones (LCZs) in the study area/city. Despite the fact that there are varying urban densities throughout a city, the idea is that the resistance will not change significantly.

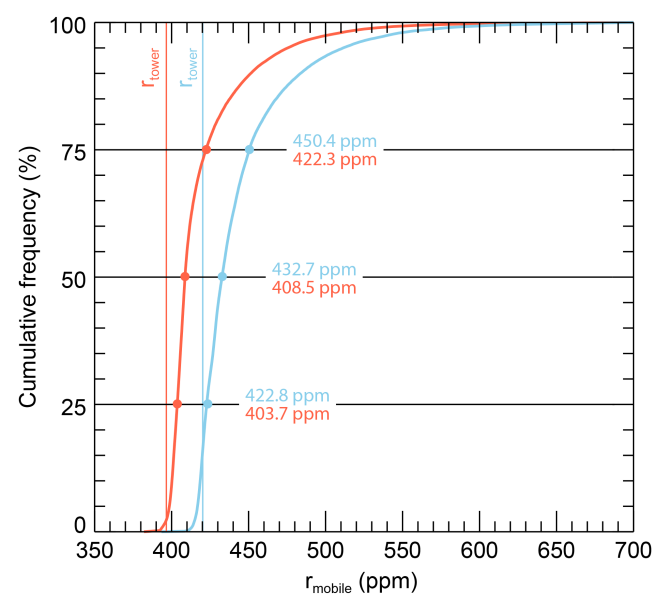

Figure 3. Cumulative frequency distribution for raw $1 \mathrm{~s} r$ measured by all five mobile systems in the summer (red) and winter (blue) campaign. The thin vertical lines correspond to the average $r$ on top of the tower during the period of the campaign. The coloured numbers on the horizontal lines refer to the 25,50 , and $75 \%$ percentiles for summer (red) and winter (blue).

4. Lateral advection of $\mathrm{CO}_{2}$ between the surface and the height of the tower between grid cells is negligible or, at least, adds random (unbiased) noise.

\section{Results}

\subsection{Field campaign}

Weather conditions on both dates were cloudless, convective, and steady. Table 1 summarizes the weather and environmental conditions for the two campaigns.

\subsubsection{Raw data points}

A total of $410271 \mathrm{~Hz}$ measurements were available in summer and 42786 measurements in winter from the $5 \mathrm{DIYSCO}_{2}$ systems during a $3.5 \mathrm{~h}$ window after filtering. Figure 3 shows the frequency distribution of the filtered $1 \mathrm{~Hz}$ $r_{\text {mobile }}$ measured by all five $\mathrm{DIYSCO}_{2}$ systems alongside the mixing ratio on the tower $\left(r_{\text {tower }}\right)$.

In summer, the measured $1 \mathrm{~Hz} r_{\text {mobile }}$ ranged from 380.2 to $918.1 \mathrm{ppm}$ with a median and average $r$ of 408.5 and $419.5 \mathrm{ppm}$ (SD $32.35 \mathrm{ppm}$ ), respectively, for the entire dataset. The lowest $r_{\text {mobile }}(<400 \mathrm{ppm})$ was measured in the forest at "Stanley Park", in select well-vegetated residential streets, and in a large cemetery. The highest values $(>800 \mathrm{ppm})$ were measured in "Downtown" and along the major transport corridors such as "Knight St." (Fig. 4) and "West Georgia St." (Highway 99). In winter, overall $r$ was higher for both tower and mobile system. In winter, the measured $1 \mathrm{~Hz} r_{\text {mobile }}$ ranged from 401.4 to $918.5 \mathrm{ppm}$ with 
Table 1. Summary of weather conditions during the two campaigns (from 09:00 to 13:00 PST) measured on top of the urban climate tower "Vancouver-Sunset" (Ca-VSu) located within the study transect.

\begin{tabular}{lrr}
\hline & $\begin{array}{r}\text { Summer } \\
\text { May 2015 }\end{array}$ & $\begin{array}{r}\text { Winter } \\
18 \text { March } 2016\end{array}$ \\
\hline Surface temperature & $31.0^{\circ} \mathrm{C}$ & $15.2^{\circ} \mathrm{C}$ \\
Relative humidity $(26.0 \mathrm{~m})$ & $71.5 \%$ & $36.2 \%$ \\
Solar irradiance $(26.2 \mathrm{~m})$ & $817 \mathrm{~W} \mathrm{~m}^{-2}$ & $475 \mathrm{~W} \mathrm{~m}^{-2}$ \\
Net radiation $(26.2 \mathrm{~m})$ & $680 \mathrm{~W} \mathrm{~m}^{-2}$ & $323 \mathrm{~W} \mathrm{~m}^{-2}$ \\
Sensible heat flux $(28.8 \mathrm{~m})$ & $390 \mathrm{~W} \mathrm{~m}^{-2}$ & $120 \mathrm{~W} \mathrm{~m}^{-2}$ \\
Wind speed $(28.8 \mathrm{~m})$ & $2.6 \mathrm{~m} \mathrm{~s}^{-1}$ & $1.9 \mathrm{~m} \mathrm{~s}^{-1}$ \\
Wind direction $(28.8 \mathrm{~m})$ & $237^{\circ}$ & $70^{\circ}$ \\
$\mathrm{CO}_{2}$ mixing ratio $(28.8 \mathrm{~m})$ & $396.6 \mathrm{ppm}$ & $420.2 \mathrm{ppm}$ \\
\hline
\end{tabular}

a median and average $r_{\text {mobile }}$ of 432.7 and $443.9 \mathrm{ppm}$ (SD $34.77 \mathrm{ppm})$.

During the summer and winter campaigns, $2 \%$ and $16 \%$ of the measured $r_{\text {mobile }}$ were lower than the tower $\left(r_{\text {tower }}\right)$ and $3 \%$ and $7 \%$ were higher than $500 \mathrm{ppm}$, respectively.

\subsubsection{Grid sample counts}

For the $100 \times 100 \mathrm{~m}$ grid cells that could be traversed, in summer $91.31 \%$ of the grid cells contained more than 10 samples per grid cell (1 sample equals one $1 \mathrm{~Hz}$ measurement), $69.24 \%$ of cells contained more than 20 samples, and $28.32 \%$ of cell contained more than 50 samples. At the average vehicle speed of $20 \mathrm{~km} \mathrm{~h}^{-1}$, this corresponds to a typical spatial spacing of $5.5 \mathrm{~m}$. For the winter campaign, $90.85 \%$ of the grid cells contained more than 10 samples, $72.64 \%$ contained more than 20 samples, and $27.36 \%$ contained more than 50 samples. Grid cells with less than 10 samples were removed from further analysis, which resulted in $30.8 \%$ of all cells being removed in the summer campaign and $27.4 \%$ in the winter campaign. Generally, grid cells along major roads tended to have more sample counts because they were traversed at different times, often by different vehicles.

\subsubsection{Grid-averaged statistics}

Of the 1332 grid cells that could be traversed by a car or bicycle, the case study covered 1024 in summer and 1037 in winter, of which 821 and 856 were further used (based on the condition of more than 10 samples). The maps of gridded $r_{\text {mobile }}$ for the summer and winter campaign are shown in Fig. 5. Table 2 summarizes the measured mixing ratios separated by neighbourhood. In summer, the grid-averaged $r_{\text {mobile }}$ of all valid grid cells in the entire transect ranged between 393.1 and $518.0 \mathrm{ppm}$, averaging $417.9 \mathrm{ppm}$, and had a median of $410.0 \mathrm{ppm}$. In winter, the grid-averaged $r_{\text {mobile }}$ ranged between 408.4 and $560.5 \mathrm{ppm}$, averaging $442.5 \mathrm{ppm}$. Three percent of all grid cells in summer and $8 \%$ in winter showed a $r_{\text {mobile }}$ that was lower than $r_{\text {tower }}$; the majority

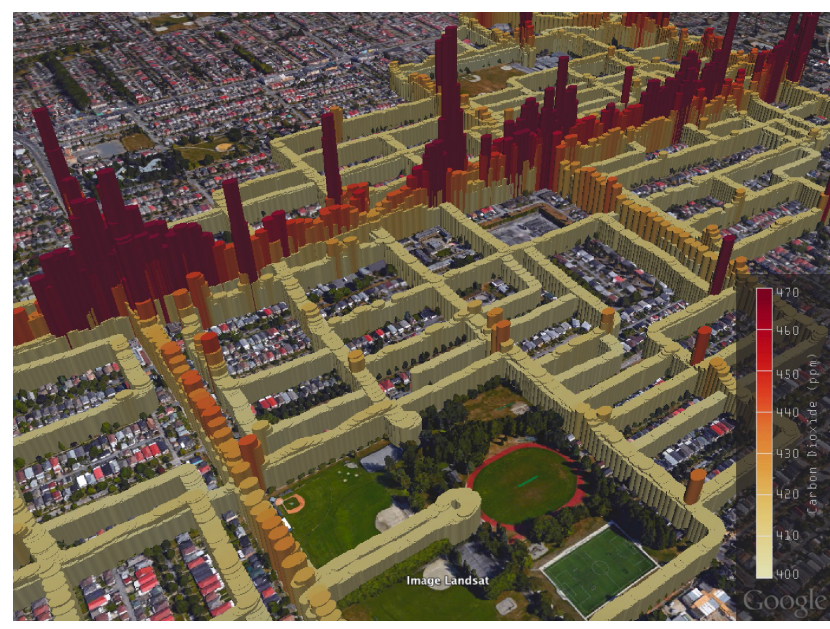

Figure 4. Three-dimensional visualization of all raw $r_{\text {mobile }}$ measurements from all systems (summer campaign) in the "Sunset/Victoria-Fraserview" neighbourhood. The visualization is illustrating the high density of measurements taken along streets, laneways, and in parks. The linear area with many higher mixing ratios is the busy six-lane "Knight St." with $\approx 50000$ vehicles per day. Image visualized in Google Earth.

of those cases were located in the forested "Stanley Park" in both campaigns (Table 2). Selected cells in the residential parts of "Riley Park/Kensington - Cedar Cottage" neighbourhood also showed a $r_{\text {mobile }}$ that was lower than $r_{\text {tower }}$.

Both campaigns showed considerable variation of $r_{\text {mobile }}$ between grid cells in the same neighbourhoods. Overall, the grid cells covering major arterial roads and downtown core showed the highest maximum, minimum, median, and mean $r_{\text {mobile }}$. Conversely, the grid cells covering residential streets and forested trails exhibited the lowest $r_{\text {mobile }}$ for the same statistics. Of all neighbourhoods, "Kensington-Cedar Cottage/Riley Park" exhibited the lowest and "Downtown" the highest average $r_{\text {mobile }}$ in both campaigns (Table 2).

Similarly, standard deviations within each $100 \mathrm{~m}$ grid cell (not shown) are highest along the major arterial roads and in "Downtown". In contrast, the residential areas have lower standard deviations within grid cells, indicating less variability in $r_{\text {mobile }}$ for less busy roads. The trends are similar in the winter campaign except that there is overall higher standard deviation in the residential areas compared to the summer campaign. Over $65.98 \%$ of the cells in summer and $66.80 \%$ in winter had a positive skewness which means there are intra-grid peaks in measured $\mathrm{CO}_{2}$ mixing ratios.

\subsubsection{Measured emissions}

The aerodynamic resistance $r_{\mathrm{aH}}$ for each measurement campaign was calculated by averaging $H$, averaging $T_{0}$, and averaging $T_{\text {tower }}$ over the $3.5 \mathrm{~h}$ of the field campaign. The resulting $r_{\mathrm{aH}}$ was $34.14 \mathrm{~s} \mathrm{~m}^{-1}$ in summer and $56.12 \mathrm{~s} \mathrm{~m}^{-1}$ in winter. 
Table 2. Grid-averaged mixing ratios $\left(r_{\text {mobile }}\right)$, standard deviation of all grid cell means in the neighbourhood, and fraction of cells with $r_{\text {mobile }}<r_{\text {tower }}$ per neighbourhood.

\begin{tabular}{|c|c|c|c|c|c|c|c|c|c|}
\hline \multirow[t]{2}{*}{ Neighbourhood } & \multirow[t]{2}{*}{$\mathrm{LCZ}^{*}$} & \multicolumn{2}{|c|}{$\begin{array}{c}\text { Mean mixing ratio } \\
r_{\text {mobile }}(\mathrm{ppm})\end{array}$} & \multicolumn{2}{|c|}{$\begin{array}{l}\text { SD of } r_{\text {mobile }} \\
(\mathrm{ppm})\end{array}$} & \multicolumn{2}{|c|}{$\begin{array}{c}\text { Fraction of cells } \\
\text { with } r_{\text {mobile }}<r_{\text {tower }}\end{array}$} & \multicolumn{2}{|c|}{$\begin{array}{l}\text { Number of } \\
\text { grid cells }\end{array}$} \\
\hline & & Summer & Winter & Summer & Winter & Summer & Winter & Summer & Winter \\
\hline Stanley Park & Dense trees & 413.7 & 435.6 & 19.1 & 24.3 & $4 \%$ & $28 \%$ & $N=78$ & $N=86$ \\
\hline West End & Compact high-rise & 416.1 & 442.7 & 15.1 & 15.9 & $1 \%$ & $4 \%$ & $N=102$ & $N=111$ \\
\hline Downtown & Compact high-rise & 437.8 & 474.9 & 19.2 & 26.5 & $0 \%$ & $0 \%$ & $N=117$ & $N=115$ \\
\hline Fairview/Mount Pleasant & Open low-rise \& large low-rise & 421.2 & 446.2 & 19.0 & 17.6 & $0 \%$ & $0 \%$ & $N=136$ & $N=144$ \\
\hline Kensington-C. C./Riley Park & Open low-rise & 411.0 & 432.3 & 13.5 & 15.1 & $1 \%$ & $11 \%$ & $N=225$ & $N=245$ \\
\hline Sunset/Victoria-Fraserview & Open low-rise & 413.3 & 434.7 & 14.2 & 16.0 & $0 \%$ & $8 \%$ & $N=163$ & $N=155$ \\
\hline
\end{tabular}

* LCZ refers to the dominant local climate zones in the neighbourhood according to Stewart and Oke (2012).

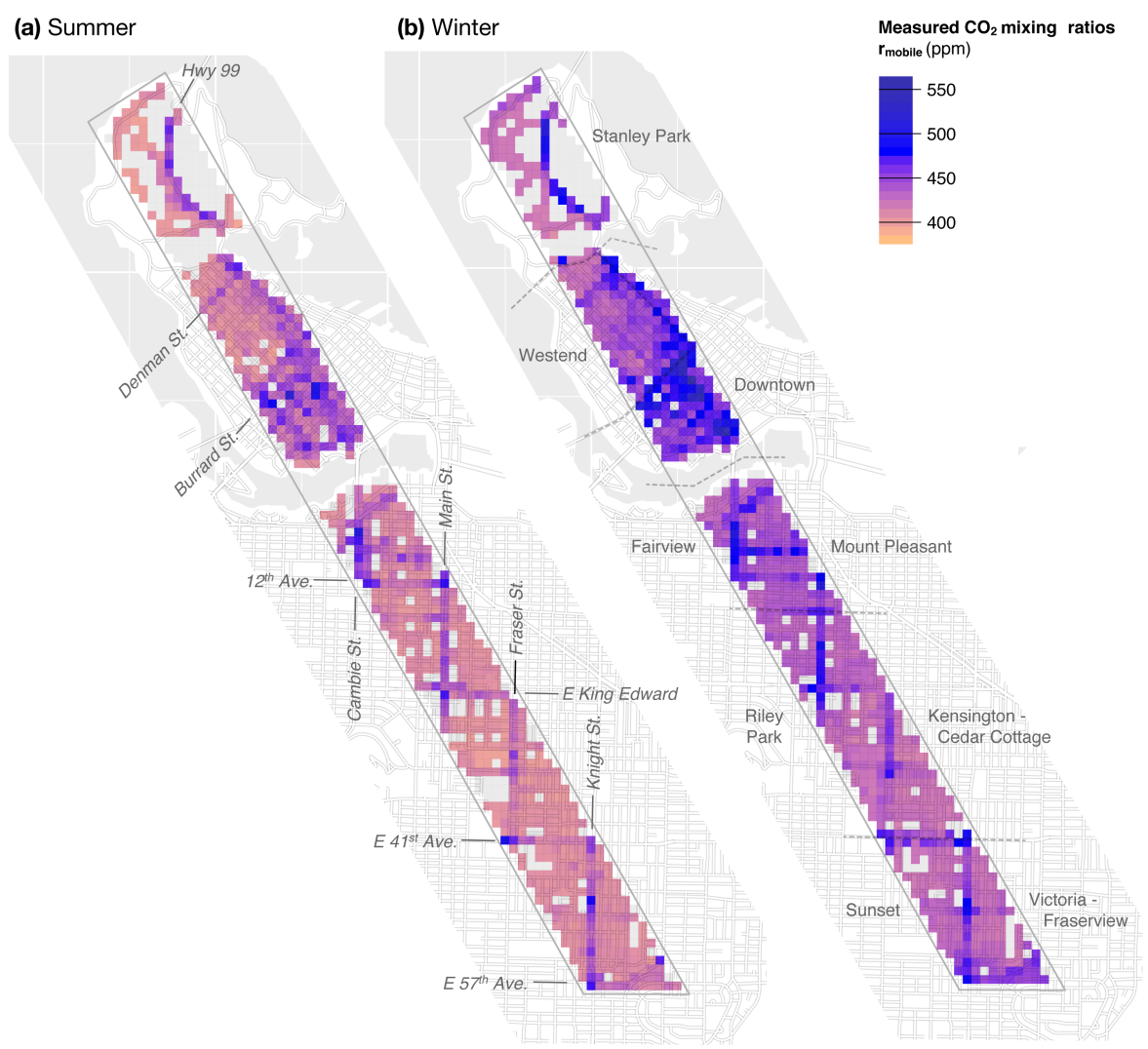

Figure 5. Map of grid-averaged $\mathrm{CO}_{2}$ mixing ratios $\left(r_{\text {mobile }}\right)$ for (a) summer and (b) winter campaign using the same scale. The grid size is $100 \times 100 \mathrm{~m}$

The measured $\mathrm{CO}_{2}$ emissions calculated using Eq. (1) showed a range of $-12.0 \mathrm{~kg} \mathrm{CO}_{2} \mathrm{ha}^{-1} \mathrm{~h}^{-1}$ (net uptake) to $225.6 \mathrm{~kg} \mathrm{CO}_{2} \mathrm{ha}^{-1} \mathrm{~h}^{-1}$ in the summer campaign and -13.7 to $162.4 \mathrm{~kg} \mathrm{CO}_{2} \mathrm{ha}^{-1} \mathrm{~h}^{-1}$ in winter. The median and average emissions were, respectively, 20.1 and $35.0 \mathrm{~kg} \mathrm{CO}_{2} \mathrm{ha}^{-1} \mathrm{~h}^{-1}$ for the summer campaign and 17.1 and $25.6 \mathrm{~kg} \mathrm{CO}_{2} \mathrm{ha}^{-1} \mathrm{~h}^{-1}$ for the winter campaign. Highest emissions in general were located in "Downtown" and along the major transport corridors and intersections (Fig. 6, Table 3).

\subsection{Comparison to emissions inventory}

\subsubsection{Characteristics of emissions inventories}

The gridded traffic emissions inventory at $100 \times 100 \mathrm{~m}$ resolution (see Appendix B1 and Fig. 7a) showed median and mean emissions, respectively, of 2.37 and $12.50 \mathrm{~kg} \mathrm{CO}_{2} \mathrm{ha}^{-1} \mathrm{~h}^{-1}$ for the summer campaign and 2.17 and $12.19 \mathrm{~kg} \mathrm{CO}_{2} \mathrm{ha}^{-1} \mathrm{~h}^{-1}$ for the winter campaign. As expected, the major roads and the areas with the densest road network (e.g. "Downtown") exhibited the highest emis- 


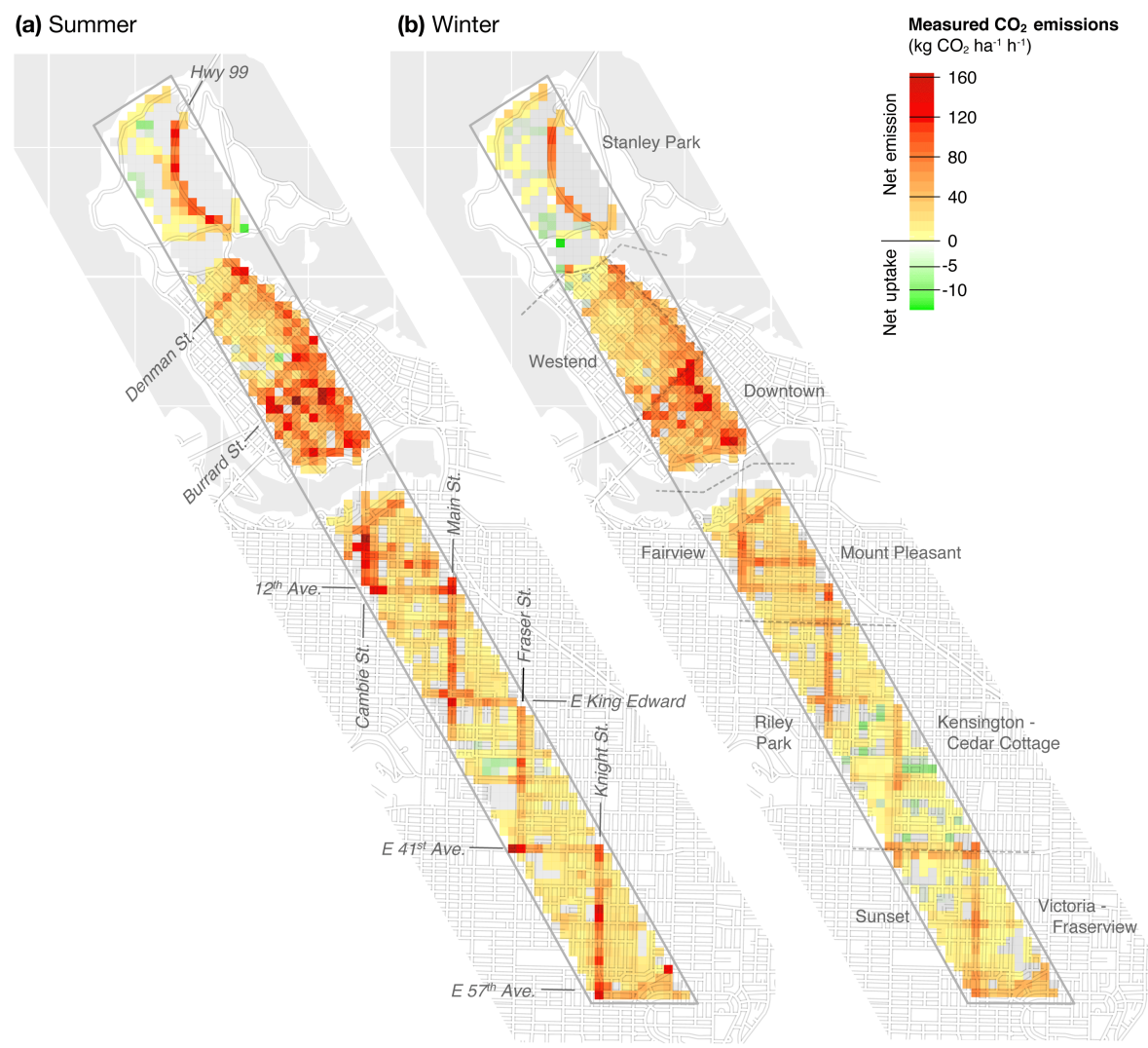

Figure 6. Measured emissions (calculated from mixing ratios using the aerodynamic resistance approach in Eq. 1) for (a) summer and (b) winter campaign at a resolution of $100 \times 100 \mathrm{~m}$.

sions, all of which were greater than $18 \mathrm{~kg} \mathrm{CO}_{2} \mathrm{ha}^{-1} \mathrm{~h}^{-1}$. The greatest traffic emissions in a single grid cell was $123.60 \mathrm{~kg} \mathrm{CO}_{2} \mathrm{ha}^{-1} \mathrm{~h}^{-1}$.

The building emissions inventory (see Appendix B2) is shown in Fig. 7b. In summer, the data for the $100 \mathrm{~m}$ grid showed a median and mean of 6.69 and $10.19 \mathrm{~kg} \mathrm{CO}_{2} \mathrm{ha}^{-1} \mathrm{~h}^{-1}$, respectively. In winter, the data for the $100 \mathrm{~m}$ grid showed a higher median and a higher mean of 13.08 and $20.44 \mathrm{~kg} \mathrm{CO}_{2} \mathrm{ha}^{-1} \mathrm{~h}^{-1}$, respectively. The maximum rate of building emissions was located in "Downtown". The building emissions inventory only covers a subset of the transect area (Fig. 7b). Data for part of "West End" and for "Stanley Park" are not available.

The total emissions inventory is the sum of the building and traffic emissions estimates (Fig. 7c). For the summer campaign, the median and mean of the total emissions estimates were 10.15 and $22.06 \mathrm{~kg} \mathrm{CO}_{2} \mathrm{ha}^{-1} \mathrm{~h}^{-1}$, respectively. Overall, for the area with both inventories available, 59\% of the emissions were estimated from traffic and $41 \%$ from buildings. For the winter campaign, the total emissions estimates were 15.87 and $28.76 \mathrm{~kg} \mathrm{CO}_{2} \mathrm{ha}^{-1} \mathrm{~h}^{-1}$, respectively, and $41 \%$ of the emissions were estimated from traffic and $59 \%$ from buildings. The fraction of traffic emissions is higher in the detached residential areas (LCZ 6 and 8) and lower in "Downtown" (Table 3).

\subsubsection{Mixing ratios vs. emissions inventory}

First, measured $r_{\text {mobile }}$ was compared to the emissions estimates to identify if there is a direct relationship between measured mixing ratios and hourly emissions estimates from the emissions inventory. It is observed that as emissions in the inventory increase, the range of the measured $r_{\text {mobile }}$ becomes greater. The relationship between measured $r_{\text {mobile }}$ and traffic shows generally a linear correlation (Fig. 8a and b). Further, measured $r_{\text {mobile }}$ and building emissions are also positively correlated, but with more scatter (Fig. 8c and d). Best agreement is archived when comparing $r_{\text {mobile }}$ to the total (i.e. traffic + building) emissions (Fig. 8e and f). The linear equations given in Fig. 8e show $R^{2}=0.53$ in summer and $R^{2}=0.47$ in winter.

\subsubsection{Measured emissions vs. emissions inventory}

Figure $9 \mathrm{a}$ and $\mathrm{b}$ show the measured emissions as a function of the traffic emissions inventory. The data show that $86.71 \%$ of the measured emissions are within a factor of \pm 10 of the traf- 
Table 3. Comparison of measured emissions, with inventory emissions, separated by neighbourhood based on a $100 \times 100 \mathrm{~m}$ grid.

\begin{tabular}{|c|c|c|c|c|c|c|}
\hline Neighbourhood & $\begin{array}{r}\text { Measured } \\
\text { emissions } \\
\left(\mathrm{kg} \mathrm{CO}_{2}\right. \\
\left.\mathrm{ha}^{-1} \mathrm{~h}^{-1}\right)\end{array}$ & $\begin{array}{r}\text { Emission } \\
\text { inventory } \\
\left(\mathrm{kg} \mathrm{CO}_{2}\right. \\
\mathrm{ha}^{-1} \mathrm{~h}^{-1}\end{array}$ & $\begin{array}{r}\text { Relative } \\
\text { error }\end{array}$ & $\begin{array}{r}\text { Mean absolute } \\
\text { error } \\
\left(\mathrm{kg} \mathrm{CO}_{2}\right. \\
\left.\mathrm{ha}^{-1} \mathrm{~h}^{-1}\right)\end{array}$ & $\begin{array}{l}\text { Fraction } \\
\text { of traffic }\end{array}$ & $\begin{array}{l}\text { Grid } \\
\text { cells }\end{array}$ \\
\hline \multicolumn{7}{|l|}{ Summer } \\
\hline West End & 47.6 & 30.4 & $+56 \%$ & 29.3 & $34 \%$ & $N=21$ \\
\hline Downtown & 75.1 & 63.3 & $+19 \%$ & 28.9 & $54 \%$ & $N=90$ \\
\hline Fairview/Mount Pleasant & 41.4 & 27.4 & $+51 \%$ & 19.7 & $70 \%$ & $N=136$ \\
\hline Kensington-C. C./Riley Park & 21.9 & 14.5 & $+51 \%$ & 10.9 & $60 \%$ & $N=225$ \\
\hline Sunset/Victoria-Fraserview & 26.5 & 13.3 & $+99 \%$ & 15.3 & $73 \%$ & $N=162$ \\
\hline \multicolumn{7}{|l|}{ Winter } \\
\hline West End & 30.1 & 43.4 & $-31 \%$ & 24.8 & $22 \%$ & $N=24$ \\
\hline Downtown & 65.3 & 92.1 & $-29 \%$ & 41.6 & $35 \%$ & $N=92$ \\
\hline Fairview/Mount Pleasant & 30.3 & 34.7 & $-13 \%$ & 14.6 & $52 \%$ & $N=142$ \\
\hline Kensington-C. C./Riley Park & 14.0 & 19.4 & $-28 \%$ & 10.1 & $40 \%$ & $N=244$ \\
\hline Sunset/Victoria-Fraserview & 16.8 & 17.1 & $-2 \%$ & 12.4 & $56 \%$ & $N=155$ \\
\hline
\end{tabular}

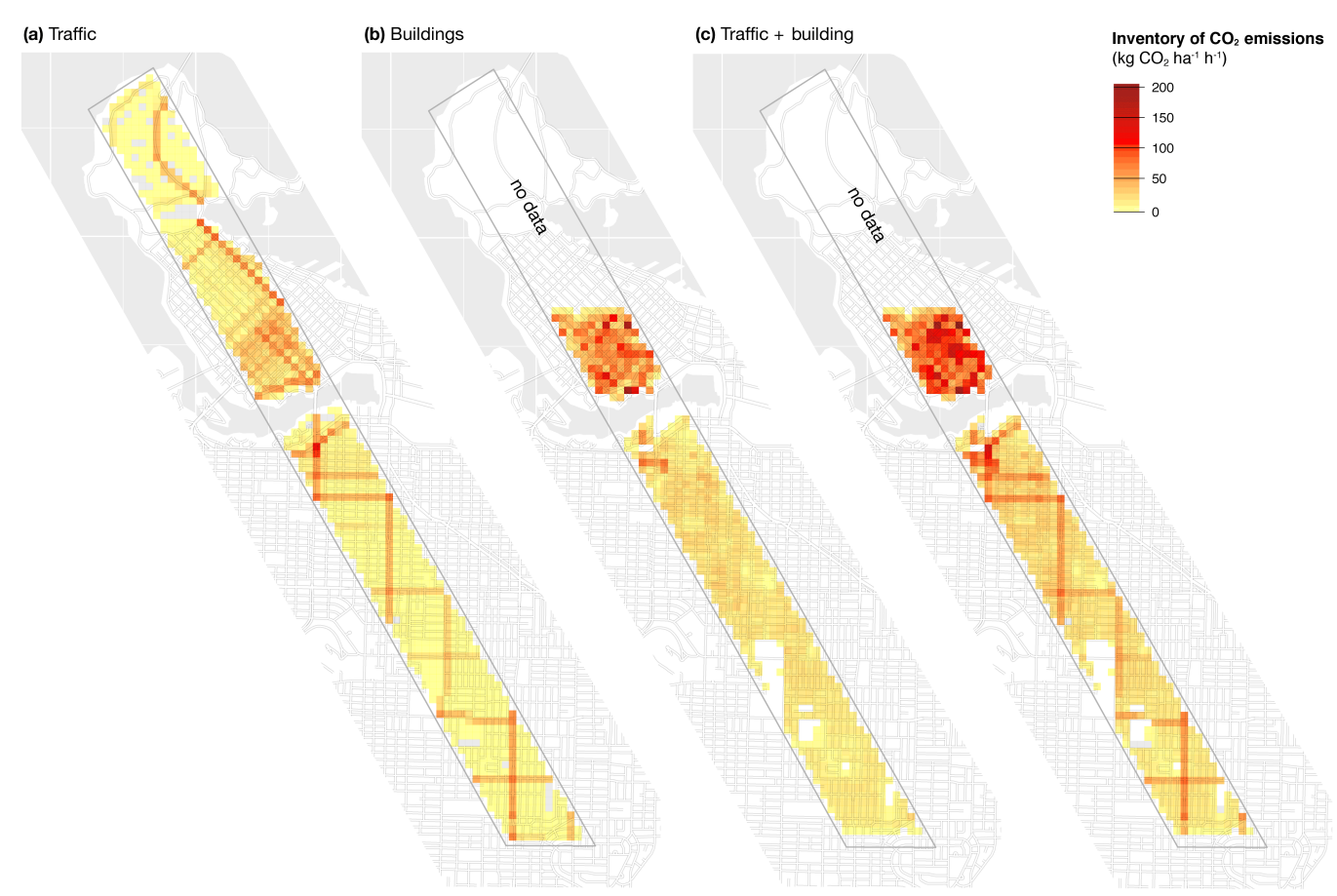

Figure 7. Emission inventory for (a) traffic emissions, (b) local building sector emissions, and (c) total (traffic + buildings) emissions for the time of the winter campaign. The equivalent emission inventory for the summer date (not shown) does not look significantly different, but it has overall lower building emissions. Note that the building inventory, available from a previous study, did not extend into the northern part of the transect (label "no data") due to lack of high-resolution lidar data in this part of the city.

fic emissions estimates for $100 \mathrm{~m}$ grids for the summer campaign (grey shaded area in Fig. 9). For the winter campaign, $93.74 \%$ of the measured emissions are within a factor of \pm 10 of the traffic emissions estimates for $100 \mathrm{~m}$ grids. In particular in areas with lower traffic emissions and where the urban density is lower (e.g. "Sunset/Victoria-Fraserview") the mea- surements are higher than the emission inventory (note that building emissions are not considered in Fig. 9a and b). The measured emissions and the traffic emissions inventory were found to be correlated positively by $77.87 \%$ for the $100 \mathrm{~m}$ grid in the summer campaign and $71.75 \%$ in the winter campaign. 
(a) Traffic emissions

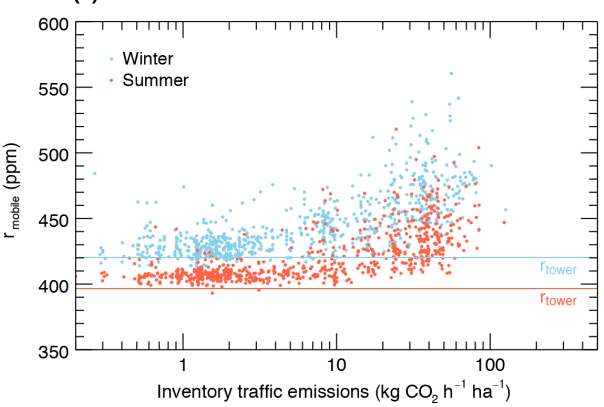

(c) Building emissions

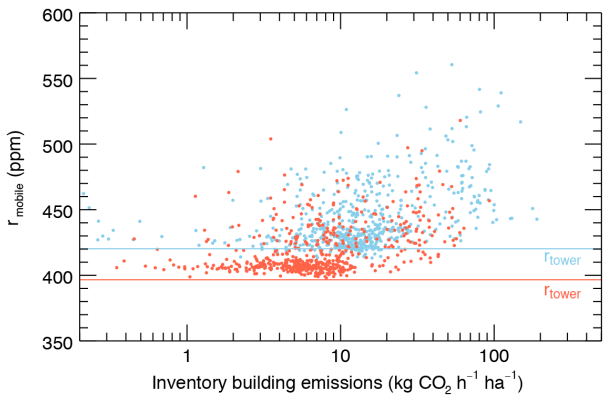

(e) Traffic + building emissions

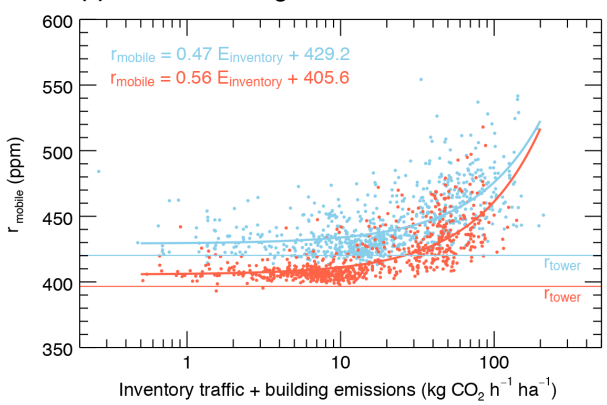

(b) Traffic emissions

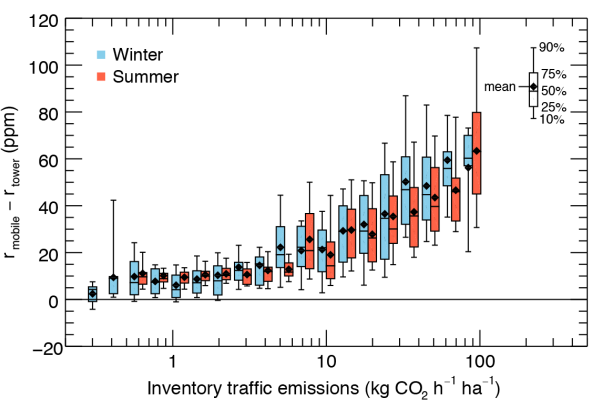

(d) Building emissions

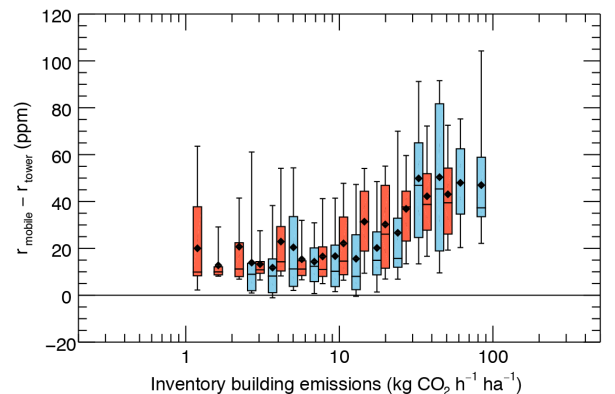

(f) Traffic + building emissions

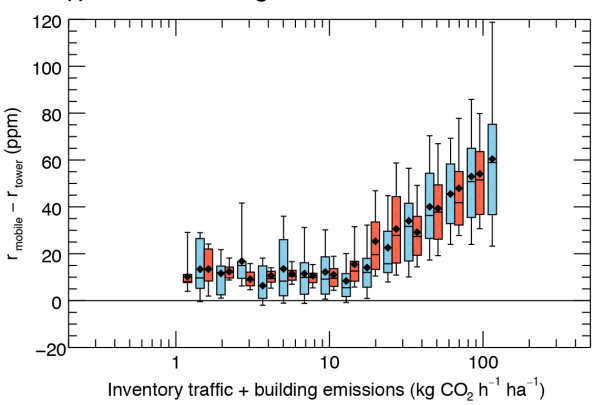

Figure 8. (a, c, e) Comparison of inventory (traffic only, building emissions only, and total emissions) against grid-averaged mixing ratios $\left(r_{\text {mobile}}\right)$, where each dot is a $100 \times 100 \mathrm{~m}$ grid cell. Note that the $x$ axis is logarithmic. The curves in (e) are linear fits. (b, d, f) Comparison of inventory (traffic only, building emissions only, and total emissions) to the difference between grid-averaged mixing ratio $r_{\text {mobile }}$ and the mixing ratio measured at the tower.

In Fig. 9c and $\mathrm{d}$ measured emissions and the building emissions inventories are compared for each grid cell. Building emissions are clustered by neighbourhood, with the lowest urban density (LCZ 6) of "Sunset/Victoria-Fraserview" exhibiting the lowest emissions and the highest urban density (LCZ 1) of "Downtown" exhibiting the highest building emissions. Across all neighbourhoods, the measured emissions are higher than the building emissions only (note that traffic emissions are not considered in Fig. 9c and d). The measured emissions and the building emissions estimates were found to be correlated positively by $35.91 \%$ for the $100 \mathrm{~m}$ grid in the summer campaign and $32.42 \%$ in the winter campaign.
Lastly, Fig. 9c shows the measured emissions as a function of the total emissions (building + traffic) inventory. For the summer campaign the data show that $86.71 \%$ of the measured emissions are within a factor of \pm 10 of the total emissions estimates for the $100 \mathrm{~m}$ grid. The measured emissions and the total emissions inventory were found to be correlated positively by $77.87 \%$ for the $100 \mathrm{~m}$ grid. For the winter campaign, the data show that $92.58 \%$ of the measured emissions are within a factor of \pm 10 of the total emissions estimates for $100 \mathrm{~m}$ grid. The measured emissions and the total emissions inventory were found to be correlated positively by $71.75 \%$ for the $100 \mathrm{~m}$ grid. 
(a) Summer (traffic only)

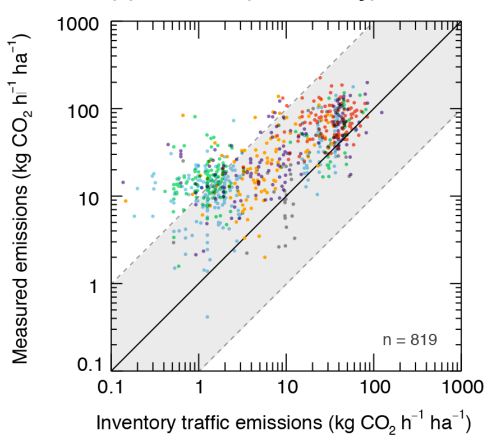

(c) Summer (buildings only)

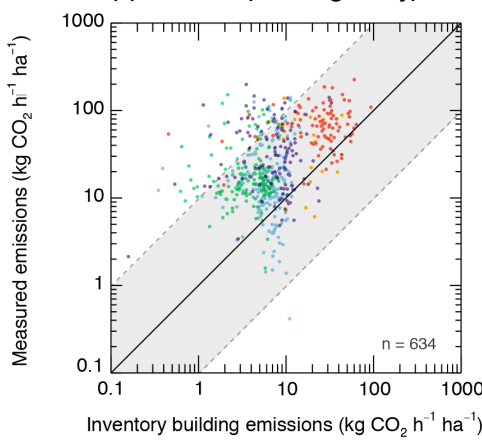

(b) Winter (traffic only)

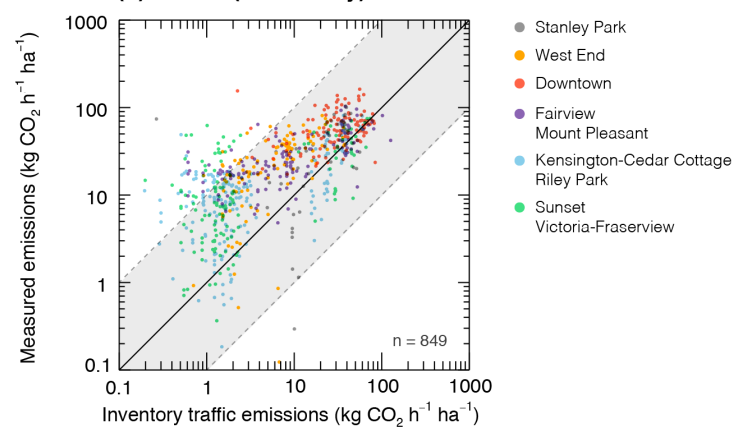

(d) Winter (buildings only)

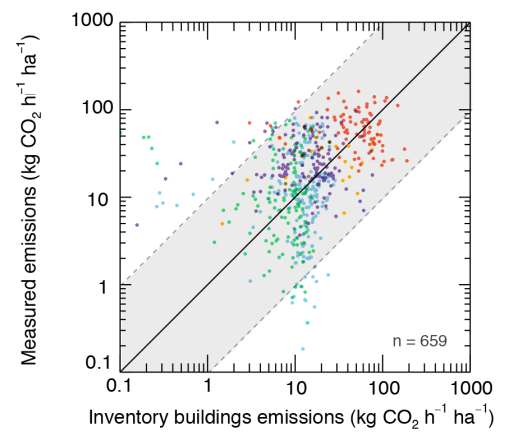

(e) Summer (traffic + buildings)
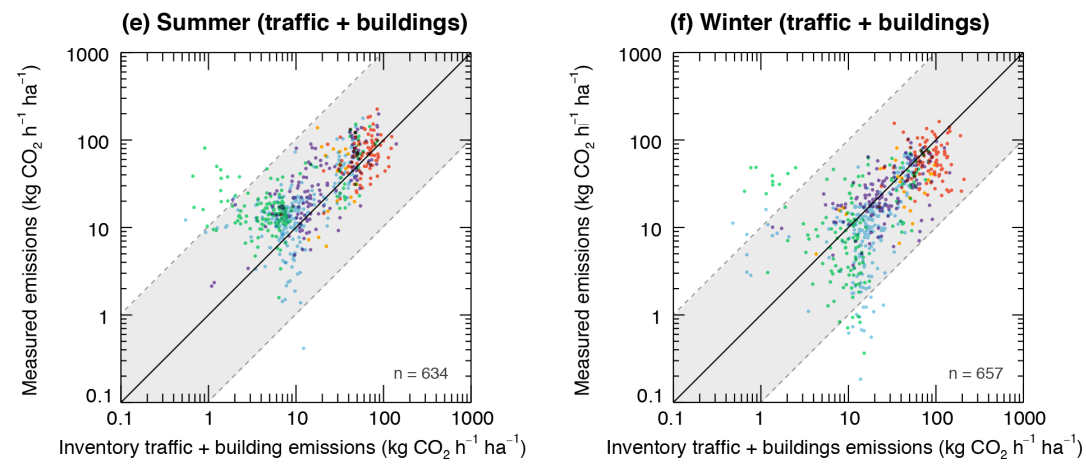

Figure 9. Comparison of inventory emissions and measured emissions on a grid-by-grid basis plotted with double logarithmic axes. The black line is the $1: 1$ curve and the grey area shows data within 1 order of magnitude of each other. Grid cells with less than $0.1 \mathrm{~kg} \mathrm{CO}_{2} \mathrm{ha}^{-1} \mathrm{~h}^{-1}$ in the emission inventory and/or measured emissions are not shown. $n$ refers to the number of grid cells included in the comparison.

Across all valid grid cells in the study area, the measured emissions in summer averaged to $35.11 \mathrm{~kg} \mathrm{CO}_{2} \mathrm{ha}^{-1} \mathrm{~h}^{-1}$ as compared to $22.06 \mathrm{~kg} \mathrm{CO}_{2} \mathrm{ha}^{-1} \mathrm{~h}^{-1}$ of the emissions inventory. In winter, the measured emissions averaged to $25.92 \mathrm{~kg} \mathrm{CO}_{2} \mathrm{ha}^{-1} \mathrm{~h}^{-1}$ as compared to $28.76 \mathrm{~kg} \mathrm{CO}_{2} \mathrm{ha}^{-1} \mathrm{~h}^{-1}$ of the emissions inventory.

In summer, $73 \%$ of the grid cells show measured emissions that are greater than the corresponding grid cells of the total emissions inventory. For the winter campaign, only $35 \%$ of the measured emissions are greater than the total emissions inventory. For both the summer and winter campaigns, emission measurements are higher than the inventory in grid cells along major arterial roads whereas the measurements are lower than the inventory in residential areas and in "Downtown".

The mean absolute error (MAE) for all grid cells in the entire transect between measured and modelled total emissions is $17.1 \mathrm{kgCO}_{2} \mathrm{ha}^{-1} \mathrm{~h}^{-1}$ in summer and $16.6 \mathrm{~kg} \mathrm{CO}_{2} \mathrm{ha}^{-1} \mathrm{~h}^{-1}$ in winter. The median absolute error for the entire transect is 9.6 in summer and 9.9 in winter. Table 3 lists the MAE by neighbourhood. The MAE is about a factor of 2 larger in "Downtown" and "West End" compared to the residential and industrial neighbourhoods. 
The relative error (RE) is defined as the difference between a grid cell's measured emission and the same cell's emissions inventory divided by the cell's emissions inventory. The data for the $100 \mathrm{~m}$ grid show that $62 \%$ of the grid cells in summer and $81 \%$ in winter have an RE within a factor of \pm 1 . As expected, locations with higher REs were locations in which the building and traffic emissions inventories estimated almost zero but measured emissions were higher. When excluding grid cells with emissions $<10 \mathrm{~kg} \mathrm{CO}_{2} \mathrm{ha}^{-1} \mathrm{~h}^{-1}$ ) in the inventory, $80 \%$ of the grid cells in summer and $91 \%$ in winter have an $\mathrm{RE}$ with a magnitude of less than \pm 1 .

\section{Discussion}

\subsection{Assessment of the measurement methodology}

Overall, the developed approach lead to realistic and consistent results. The spatial patterns of measured emissions are plausible and generally match the fine-scale inventories of traffic and buildings although at the scale of an individual grid cell, large errors up to an order of magnitude are observed. The study was also able to replicate in the winter campaign the spatial patterns and the magnitude found in summer. The results demonstrate the potential to apply an aerodynamic resistance approach to measuring emissions using a network of mobile sensors and data from an urban climate tower.

Building and traffic emissions are both good predictors of $r_{\text {mobile }}$ measured in a city at ground level. This implies that values of $r_{\text {mobile }}$, from microscale to neighbourhood scales, are related the $\mathrm{CO}_{2}$ emissions being generated at those scales (and presumably this also holds for primary, less reactive air pollutants). This suggests that it is possible to link $r$ to emissions across a complex landscape under specific, stationary atmospheric conditions. Nevertheless, several challenges remain.

Overall, the building emissions were less clearly correlated with the spatial variability in $r$ than traffic emissions which were a better predictor. Building emissions of $\mathrm{CO}_{2}$ (natural gas burning) are most likely injected into the atmosphere at roof level (chimneys), where higher winds blend them in the process of downward mixing into streets and laneways where mobile sensors were operated. As a result of this blending, the signal of $r$ might show less spatial variability if emissions originate from buildings (far from sensor) compared to situations near ground-level emissions (car exhaust on arterial roads). Measured emissions generally tend to underestimate the inventory in "Downtown" where there is a high density of tall buildings that vent their emissions usually at higher storeys, likely decoupled from the grid cells at the ground. Consequently, the observed peaks in $r$ are more likely to be a result of traffic emissions alone.

Data can be compared to an independent previous study by Christen et al. (2011) that measured and mod- elled emissions within a $1.9 \times 1.9 \mathrm{~km}$ study area centred on the "Vancouver-Sunset" tower (see Fig. 2). In the $1.9 \times 1.9 \mathrm{~km}$ area, emissions were modelled to be $34.0 \mathrm{~kg} \mathrm{CO}_{2} \mathrm{ha}^{-1} \mathrm{~h}^{-1}$ and measured emissions by eddy covariance were $30.8 \mathrm{~kg} \mathrm{CO}_{2} \mathrm{ha}^{-1} \mathrm{~h}^{-1}$. The current study estimates emissions for the "Sunset/Victoria-Fraserview" neighbourhood (that is larger than the area in Christen et al., 2011, Fig. 2) for $18 \mathrm{March}$ (winter) as only $16.8 \mathrm{~kg} \mathrm{CO}_{2} \mathrm{ha}^{-1} \mathrm{~h}^{-1}$. For the month of May, Christen et al. (2011) report modelled emissions of $26.9 \mathrm{~kg} \mathrm{CO}_{2} \mathrm{ha}^{-1} \mathrm{~h}^{-1}$ and measured emissions of $26.0 \mathrm{~kg} \mathrm{CO}_{2} \mathrm{ha}^{-1} \mathrm{~h}^{-1}$. The current study matches extremely well here, with emissions for "Sunset/VictoriaFraserview" on 28 May (summer) of $26.5 \mathrm{~kg} \mathrm{CO}_{2} \mathrm{ha}^{-1} \mathrm{~h}^{-1}$. Note that not only the spatial extent but also the timescales of the two studies disagree. Christen et al. (2011) report monthly $24 \mathrm{~h}$ emissions for the years 2008-2010, while the current study is restricted to weekdays between 10:00 and 13:30 on the two given dates.

In selected areas negative net ecosystem exchange (NEE) were detected, such as in the forest at "Stanley Park", in some highly vegetated urban residential areas and the lawn area of a cemetery. This is plausible, because most grid cells have likely some uptake by photosynthesis of urban vegetation, but in many cells the emissions from combustion and respiration combined are greater than photosynthesis. In comparing our lowest measured emissions from "Stanley Park" (-12 $\left.\mathrm{kg} \mathrm{CO}_{2} \mathrm{ha}^{-1} \mathrm{~h}^{-1}\right)$ to a study by Humphreys et al. (2006) who measured NEE for a forest with similar stand composition (Douglas fir forest on Vancouver Island, $200 \mathrm{~km}$ to the W) in April and June in the same latitude. We find that our measured emissions were within a factor of 2 of those observed in a typical forest at the same time of day and year.

\subsection{Possible refinements and errors}

Ultimately, the comparison of measured emissions and the emissions inventories showed where there might be close alignment or divergences between the datasets and suggests promising new research opportunities for improving the proposed methodology and/or emissions inventories.

\subsubsection{Aerodynamic resistance}

In terms of methodology, $r_{\mathrm{aH}}$ is calculated using $T_{\text {tower }}$ and $T_{0}$ at a single location and is likely not representative for the entire city. There is evidence of varying aerodynamic resistances across the study area. For example in the narrow street canyons of "Downtown" and in forested "Stanley Park", it is likely that the aerodynamic resistance is higher, because of the sheltered nature of the deep canyons and forest canopy, respectively. Generally, measured emissions could possibly be overestimated in streets with a denser tree canopy regardless if the canopy is vegetation or buildings. An area with a dense tree canopy may actually reduce mixing (Jin et al., 2014) and, as a result, the measured $r_{\text {mobile might be higher }}$ 
than emissions propose with a constant $r_{\mathrm{aH}}$ across the study area. It would therefore be beneficial to consider variable aerodynamic resistances and to use models that relate canopy porosity to create maps of variability in $r_{\mathrm{aH}}$. Further experiments should be done to determine how $r_{\mathrm{aH}}$ and consequently the resulting $F_{c}$ change when using different methods of estimating $r_{\mathrm{aH}}$.

\subsubsection{Averaging procedure}

A methodology to improve the grid averaging would be to sub-sample larger grid cells using a finer-scale grid (e.g. $20 \mathrm{~m} \times 20 \mathrm{~m}$ or less) and then to average those finer grid cells to lower grid resolutions as done in Crawford and Christen (2014). This would help to reduce some errors at two critical moments. First, it may be possible to average out some of the extreme values within a grid cell that may be contributing to an over- or underestimation of emissions within a grid cell due to a spatial sampling bias. Second, it offers a possibility to determine the representativeness of the grid cell sample and attribute a certainty or weight to each cell. Because the current methodology simply spatially attributes any point(s) to the grid cell in which it intersects, we do not account for the degree in which point measurements represent the spatial mean of grid cells.

\subsubsection{Emission inventories}

Several factors may account for the differences due to errors in the emission inventories. First, the emissions inventories were not based on real-time models of the data for the period of the measurement campaign. The building emissions inventory presents a challenge when comparing the grid-averaged $r$ and the measured emissions because the building emissions inventory is downscaled to an hourly average from a yearly estimate. This hourly average is assumed to be constant over the course of the day, however, studies (e.g. Martani et al., 2012) show that most building occupancy (and therefore energy use) occurs between 09:00 and 19:00, with peaks around 13:00 and 16:00. Furthermore, this does not address the fact that spatially, building energy use changes throughout the day as people go to and from work and home. Future work might attempt to quantify the spatial ebb and flow of people using a combination of surveys, census data, and methods using call detail records to derive home versus work locations as shown in Holleczek et al. (2014). Building energy use intensity might be modelled by season and diurnally based on factors such as building occupancy, building age, form, and function.

To explain differences in the traffic emissions inventory, we must account for the fact that the traffic emissions inventory was derived from spatially and temporally disaggregated samples of short-term traffic counts. As a result, the traffic emissions inventory may compound errors over time and space. Spatially, the traffic count dataset covers mostly the major roads, which leaves much of the residential areas unsampled. The method described in Appendix B1 is used to map traffic count values across the residential streets to overcome the missing traffic counts, but more validation is necessary to determine whether this method is appropriate. Temporally, the traffic emissions inventory is not a real-time representation of the traffic counts during the measurement campaign. Furthermore, the traffic emissions are generated using an emissions factor that is a fleet average for the emitted $\mathrm{CO}_{2}$ per litre of fuel burned. More precise estimates of emissions factor in the differences in the emissions factor by vehicle type and fuel type (Kellett et al., 2013). Last, the traffic count data do not indicate the amount of emissions from idling that occur as a result of traffic jams, which introduces another aspect of possible uncertainty within the traffic emissions inventory and can be substantially higher in urban contexts.

The total emissions inventory factors only building and traffic emissions and excludes other sources of emissions such as those from human, animal, and plant and soil respiration. Additional sources of $\mathrm{CO}_{2}$ emissions could come from human activities such as landscaping (e.g. lawnmowers and leaf blowers) and construction. For example, a study by Kellett et al. (2013) showed that, in a $1.9 \mathrm{~km} \times 1.9 \mathrm{~km}$ study area around the "Vancouver-Sunset" tower (see Fig. 2), emissions from human respiration and vegetation and soils can account for 8 and $5 \%$, respectively, of the total emissions.

Data-driven models in combination with urban surface databases (urban form, traffic) could be used to further improve the information in the post-processing and hence assist the derivation of more realistic emission maps (e.g. Moosavi et al., 2015).

\section{Conclusions}

In this study, we proposed and implemented a new approach to determine and map $\mathrm{CO}_{2}$ emissions at fine scale across a city. The approach combines multiple mobile sensors at street level with an eddy-covariance flux tower.

A portable, mobile sensor system to measure the spatial variability of $\mathrm{CO}_{2}$ mixing ratios called the $\mathrm{DIYSCO}_{2}$ was developed and tested. Five DIYSCO $\mathrm{S}_{2} \mathrm{~s}$ were deployed across a $12.7 \mathrm{~km}^{2}$ study area over a period of $3.5 \mathrm{~h}$; the average sampling density was about 40 samples ha ${ }^{-1}$. Of the $11.7 \mathrm{~km}^{2}$ study area that could be traversed, $8.5 \mathrm{~km}^{2}$ in summer and $8.2 \mathrm{~km}^{2}$ in winter were sampled with $>10$ samples per grid cell. Hence, excluding the grid cells with $<10$ samples, the sampling density was roughly $0.5 \mathrm{~km}^{2}$ sensor ${ }^{-1} \mathrm{~h}^{-1}$ over the $3.5 \mathrm{~h}$ period for the five sensors. If it is assumed that this sampling density is appropriate for representing urban-scale processes, it would require 230 coordinated mobile sensors on predefined routes to be deployed across the entire city of Vancouver $\left(115 \mathrm{~km}^{2}\right)$ to measure $\mathrm{CO}_{2}$ emissions across the 
city during the same time - obviously an effort that is not realistic.

However, as sensor parts will become cheaper in the future, possibilities exist to integrate mobile sensor systems into operational vehicles such as taxis (e.g. 600 in the city of Vancouver) and mobility-on-demand services (e.g. currently there are $>1000$ carshare vehicles in the city of Vancouver). Alternatively, the time frame could be extended and, using proper data selection, one could create composite maps from $r_{\text {mobile }}$ measured on different days under similar conditions. It would take 10 days in a coordinated effort to cover the entire city of Vancouver similarly to the current transect.

A further question to be explored is whether the current number of samples ( $>10 \mathrm{~s}$ ) per grid cell is sufficient to represent the typical emissions in the cell given the intermittent traffic and the fact that large coherent structures are mostly responsible for mixing of pollutants out of the urban canopy layer (Salmond et al., 2005; Christen et al., 2007). Would a higher density of points (including multiple campaign days) improve the correlation between measured and inventory emissions?

The method to map emissions based on the aerodynamic resistance approach is sensitive to the measurements that are used to derive the aerodynamic resistance of heat and requires that a number of assumptions and conditions are met; yet, the work shows that the aerodynamic resistance approach can be used reasonably on a scale of $100 \times 100 \mathrm{~m}$ grid cells to derive emissions from measures of aggregated mixing ratios. The measured emissions across the study area ranged from -12 to $225 \mathrm{~kg} \mathrm{CO}_{2} \mathrm{ha}^{-1} \mathrm{~h}^{-1}$ per grid cell, thus showing the possibility for this methodology to detect negative emissions (net uptake), where photosynthesis is greater than the combined combustion and respiration emissions.

The research presented is proof of concept for a future in which atmospheric sensing is integrated into urban mobility. We have shown the successful development of new technology and methodology for monitoring and mapping $\mathrm{CO}_{2}$ mixing ratios and emissions in complex urban environments, at much finer scale than previously possible. Despite the simplicity of the methodology, the study demonstrated that it is possible to measure emissions across a complex landscape with a fleet of mobile sensors, an eddy-covariance tower, and the use of the aerodynamic approach to calculating emissions.
The data gained can be used to map and validate emissions as well as be integrated into regional efforts using observations and inversion modelling (Newman et al., 2013) or even with total column measurements of $\mathrm{CO}_{2}$ from satellites.

Further, the concept could be translated to the mapping of other trace gases and air pollutants emitted from vehicles and houses, air and surface temperature, and other environmental variables that affect human health, comfort, and safety. However, due to the assumption that sources are in the canopy layer where sensors operate, the proposed methodology is not necessarily transferable to emissions whose sources are not well represented, such as fugitive natural gas emissions (methane) or volatile organic compounds or large industrial sources (tall stacks).

The development of smaller, more affordable mobile sensor systems can facilitate new methodological approaches to monitoring the urban environment. With a fleet of mobile sensors and the methodologies for processing the derived datasets, the possibility to map and consequently validate emissions inventories is promising, as is the derivation or real-time pollution and climate data in cities.

Code and data availability. Data from the two campaigns in the City of Vancouver, BC, Canada are archived under https://doi. pangaea.de/10.1594/PANGAEA.872702 (Lee et al., 2017). The datasets include individual measurements from all five sensors, gridded mixing ratios, and measured and modelled grids of $\mathrm{CO}_{2}$ emissions in the various resolutions discussed in the text.

Instructions and source code to build your own $\mathrm{DIYSCO}_{2}$ sensor can be found under https://diysco2.github.io (Micrometerology Group, 2017). In this repository, you will find the code used in the data analysis and for developing the traffic emission inventories described in Appendix B1. 


\section{Appendix A: Testing of sensor system}

Several key system specifications of the $\mathrm{DIYSCO}_{2}$ were evaluated during the prototyping, namely linearity, accuracy and drift, measurement lag time between sampling and measurement, and the effects of inlet location on measurement variability.

\section{A1 Sensor accuracy and linearity}

The accuracy of the Li-820 is ensured using a two-point calibration, performed in the lab using a zero gas and a standard span gas in the range of assumed measurement. In the current study, all standard tanks have been calibrated against primary CDML/NOAA WMO-traceable tanks with a typical error between standard and primary tanks in $r$ of $<0.15 \mathrm{ppm}$. For the current application, accuracy and linearity of the Li820 sensor are relevant in the range 400 to $500 \mathrm{ppm}$ to enable comparisons between different DIYSCO ${ }_{2}$ s operated simultaneously and also to properly compare $r_{\text {mobile }}-r_{\text {tower }}$.

To test the linearity in the range 400 to $500 \mathrm{ppm}$, a test was performed using six standard gases of known $r$ at 400 (two tanks), 413 (one tank), 457 (two tanks), and $504 \mathrm{ppm}$ (one tank). All Li-820 sensors were first left running for $2 \mathrm{~h}$ to account for the warm-up time. The DIYSCO ${ }_{2} \mathrm{~s}$ were connected to a calibration gas using a Union Tee connector. For each of the six gases, the calibration protocol called for an initial 2-min system flush and then a recording of the values for at least $1 \mathrm{~min}$ each. A minimum of 60 points per gas sample were used to calculate the average mixing ratios per tank measured by the system.

The Li-820 contained in the DIYSCO 2 showed strong linearity $\left(R^{2}\right.$ of 0.9999$)$ and a RMSE of 0.233 ppm for the four different $r$. This indicates that the IRGA is operating well within its factory specifications of $1 \mathrm{ppm}$ when calibrated and linearity and accuracy are not the limiting factor for this type of study.

\section{A2 Sensor drift}

Sensor drift is assessed to determine the $\mathrm{DIYSCO}_{2}$ 's ability to properly resolve the variability of mixing ratios during the duration of the campaign. Sensor drift was tested over the course of 7 days, with five sensors drawing in air from the same point outdoors at $\approx 3 \mathrm{~m}$ in an urban context.

The RMSE between the five systems at a $1 \mathrm{~min}$ resolution ranged between 0.2 and 3 ppm for the 7-day period and is therefore time dependent. The drift in the lab was up to $\pm 3.32 \mathrm{ppm}$ per day for individual sensors and days. Given that the field campaign was planned to be 3 to $3.5 \mathrm{~h}$ long, the maximum drift of any sensor in any $3 \mathrm{~h}$ was determined at most -0.31 and $+0.51 \mathrm{ppm}$ relative to the mean of all five sensors. During the field experiments, however, we observed a maximum drift of $+0.95 \mathrm{ppm}$ relative to the mean of all sensors, which was greater than what was found in the lab test.

\section{A3 Time constant and lag time}

The system measurement lag time is the time delay from when a measurement first enters the sample inlet of the system to when the signal is registered by the sensor. The $\mathrm{DIYSCO}_{2}$ 's measurement lag time is important to correctly attribute measurements to their geographic space.

For a given tube length and flow rate, the lag time will differ and therefore affect the system response characteristics. The values here are for a tube length of $3 \mathrm{~m}$. Lab measurements were performed in which a solenoid switch was used to pass nitrogen gas with $0 \mathrm{ppm} \mathrm{CO}_{2}$ into the sample tube inlet while simultaneously logging the exact second in which the solenoid was triggered. To calculate the lag time value for the system, the number of seconds were counted from when the sample enters the tube until $50 \%$ of the change was reached.

The measurement lag time of the $\mathrm{DIYSCO}_{2}$ system was determined to be $18.2 \mathrm{~s}$. The measurement lag time is the sum of the $16 \mathrm{~s}$ sample travel time from the inlet to the IRGA and the IRGA's time constant of $3.2 \mathrm{~s}$. We consequently used a value of $18 \mathrm{~s}$ in the post-processing to shift the GPS and observed $r_{\text {mobile }}$ time series to properly attribute measurements spatially. However, as the time constant with $3.2 \mathrm{~s}$ was higher than the nominal sampling frequency of $1 \mathrm{~Hz}$, the actual sampling frequency was less than $1 \mathrm{~s}$, leading to a positional standard deviation of the signal of $10 \mathrm{~m}$, not $5 \mathrm{~m}$ (at a typical speed of $20 \mathrm{~km} \mathrm{~h}^{-1}$ ).

\section{A4 Effects of inlet location}

Two tests were performed to examine possible sampling biases due to different sample inlet locations on a vehicle. First, a test was done with five $\mathrm{DIYSCO}_{2}$ in the same vehicle, where all the inlet tubes were bundled together at $2.2 \mathrm{~m}$ height, measuring at the same location (within a few $\mathrm{cm}$ of each other) of the vehicle (referred to as "Grouped Inlet Test"). A second test was done again with five DIYSCO $_{2}$ in the same vehicle, but with each of the inlet tubes located at different locations on the vehicle (referred to as "Ungrouped Inlet Test"). Locations tested were all again at $2.2 \mathrm{~m}$ height: one each above the driver's side front, driver's side back, passenger side front, and passenger side back window. Both test were performed in the city of Vancouver using a Toyota Tacoma Truck along a route with traffic volumes ranging from 300 to 850 vehicles per hour.

In areas with a well-mixed atmosphere and on roads with little traffic, the DIYSCO 2 systems for the grouped inlet test showed a range within $\pm 0.5 \mathrm{ppm}$ of the mean all five sensors for $1 \mathrm{~s}$ data. For the ungrouped inlet test under those same conditions, the range deteriorated to $\pm 5 \mathrm{ppm}$ of the mean. Adding the higher traffic road segments, with observations 
of higher $\mathrm{CO}_{2}$ mixing ratios, the standard deviation between all five of the $\mathrm{DIYSCO}_{2}$ locations increases for the $1 \mathrm{~Hz}$ data. With inlets grouped together, $48.9,81.16$, and $90.14 \%$ of the $1 \mathrm{~s}$ data have a standard deviation within 5,15 , and $25 \mathrm{ppm}$. The results of the ungrouped inlet test showed that $54.98,79.08$, and $87.49 \%$ of the data have a standard deviation within 5,15 , and $25 \mathrm{ppm}$, respectively, for the data collected at $1 \mathrm{~s}$. When aggregated to $1 \mathrm{~min}$, the data showed $66.67,91.66$, and $94.44 \%$ of the data have a standard deviation within 5, 15, and $25 \mathrm{ppm}$ of each other, respectively.

This indicates that slightly less than half of the $1 \mathrm{~s}$ data measured by the sensors are within $5 \mathrm{ppm}$ of each other and that we can expect a majority of the data $(>88.85 \%)$ to have errors up to $15 \mathrm{ppm}$ depending on where the inlet is mounted on the car. When examining the variability of the observed values for the $1 \mathrm{~min}$ data, 86.3 and $98.63 \%$ of the data have a standard deviation within 5 and $25 \mathrm{ppm}$. In summary, the sampling location is a source of much greater uncertainty than instrument accuracy, drift, or linearity in the context of this work.

\section{Appendix B: Emissions inventories}

This appendix described the derivation of the independent building and traffic emissions inventory that were compared against the measured $\mathrm{CO}_{2}$ emissions.

\section{B1 Traffic emissions inventory}

The fine-scale gridded traffic emissions inventory was based on hourly averaged directional traffic count data from 2008 to 2013 provided by the city of Vancouver (City of Vancouver, 2015).

For each hour of the day, traffic counts were spatially attributed to the Open Street Map (OSM) road network. The city of Vancouver provides traffic counts collected from pneumatic road tubes which are attributed to an approximate address of where the traffic counters were located. The traffic counts do not distinguish between different vehicle classes and are aggregated to the street level, meaning that, for this analysis, the traffic counts did not take into account the direction of travel.

The city also provides a geospatial representation of the locations of the traffic counters with the address, but without the count data attached. The geospatial data were merged with the count data. However, because spatial traffic counts do not align with the OSM road network, the centroids of the spatial traffic count data were computed and then "snapped" to the OSM road network. Before joining the traffic count data by the matching locations of the two datasets, the OSM road network was split into segments using the $50 \times 50 \mathrm{~m}$ vector grid. A small $(0.5 \mathrm{~m})$ buffer was applied to the traffic count centroids to ensure that they spatially match onto the OSM road network and then were merged to the OSM dataset.

An algorithm was used to match the street names in the traffic count dataset to those in the OSM street network. Manual mapping of traffic counts was necessary to attribute traffic counts to streets that were not sampled in the traffic counts. A rule of proximity and local understanding of the traffic patterns for each of the streets was used to manually map the traffic counts to the unsampled streets. Using the OSM street classifications, traffic counts for paths unnavigable by vehicles were given a value of " 0 " traffic counts, namely "steps", "trail", "footpath", and "service". Lastly, the traffic counts for forked roads in the dataset which would have doubled the count for a particular street were divided in half.

With a complete model of the traffic counts for the transect, it was then possible to generate a gridded traffic emissions inventory map of $\mathrm{CO}_{2}$ (now referred to as "traffic emissions inventory"). The length of each of the street segments which had been split in the earlier steps were calculated and then summed up per 50,100, 200, and $400 \mathrm{~m}$ grid cell. Next, the length of navigable roads per grid cell were multiplied by the hourly traffic counts along each road, resulting in an estimate of total distance of vehicle travelled per grid cell. Each grid cell's hourly travel distance was then multiplied by the NRCAN fleet standard fuel consumption (Natural Resources Canada, 2014) for urban driving (12.9 $\left.100 \mathrm{~km}^{-1}\right)$ and af ter by a $\mathrm{CO}_{2}$ emissions factor $\left(2.175 \mathrm{~kg} \mathrm{~L}^{-1}\right.$ fuel burned) (British Columbia Ministry of Transportation, 2014) to generate the traffic emissions estimate map of $\mathrm{CO}_{2}$. In this study, the traffic count data provided by the city of Vancouver are averaged across all of the years that the traffic count data have been collected. The data are then scaled by a factor 0.9985 and 1.0216 to reflect the seasonally changing relative traffic volumes for March and May based on automatic and continuous highway counts (weekday only) at five locations throughout Metro Vancouver.

\section{B2 Building emissions inventory}

The fine-scale gridded building emission inventory was developed in previous research and is documented in detail in van der Laan (2011). It integrates lidar data, building simulation software, and a building typology database to model $\mathrm{CO}_{2}$ emissions attributed to building energy use; the original building emissions inventory is on a per-building scale in carbon dioxide equivalent $\left(\mathrm{CO}_{2}\right.$ eq., reported in $\mathrm{kgCO}_{2}$ eq. year $\left.{ }^{-1}\right)$. In this research, it is assumed that $\mathrm{CO}_{2}$ eq. and $\mathrm{CO}_{2}$ are the same for building heating systems. This is then converted to a $1 \mathrm{~m}$ raster using building footprints derived from lidar and property perimeters. The $1 \mathrm{~m}$ raster was then averaged to the $50,100,200$, and $400 \mathrm{~m}$ vector grids and scaled to their estimated hourly values for both campaigns.

Because the inventory by van der Laan (2011) reports annual estimates (in $\mathrm{kg} \mathrm{CO}_{2}$ eq. $\mathrm{m}^{-2}$ year $^{-1}$ ), a scaling factor 
based on monthly city emissions inventory was used in this study to account for the winter and summer building emissions fraction. In the months of March and May, the building emissions for a sample of the city of Vancouver were estimated to be 99.85 and $63.63 \%$ of the annual average building emissions (reported in Christen et al., 2011). The final building emissions inventory was reported in $\mathrm{kg} \mathrm{CO}_{2} \mathrm{ha}^{-1} \mathrm{~h}^{-1}$. In this case, it is assumed that the building emissions are constant over the course of the day.

Each grid cell of the total emissions inventory is simply the sum of the building emissions inventory and the traffic emissions inventory in $\mathrm{kg} \mathrm{CO}_{2} \mathrm{ha}^{-1} \mathrm{~h}^{-1}$. Other emission processes such as human respiration or biological processes are not considered in the inventory.

\section{Appendix C: Effect of grid size}

In addition to the $100 \times 100 \mathrm{~m}$ grid, the raw data points were also gridded to 50,200 , and $400 \mathrm{~m}$ vector grids for both the winter and summer campaigns to explore the sensitivity of choosing different grid sizes.

\section{C1 Effects on spatially averaged mixing ratios}

Changes in grid size affected the study area mean $r_{\text {mobile }}$ by $6.1 \mathrm{ppm}$ in the summer and only $1.1 \mathrm{ppm}$ in the winter. Table $\mathrm{C} 1$ summarizes the statistics for different grid cell sizes. The grid maximum values for the 50,100,200, and $400 \mathrm{~m}$ grids were $529.8,518.0,488.2$, and $447.7 \mathrm{ppm}$ for the summer and $643.1,560.5,529.4$, and $492.5 \mathrm{ppm}$ for the winter, respectively.

The highest grid maximums were observed in the $50 \mathrm{~m}$ grid size. This is expected because the most extreme $r_{\text {mobile }}$ are spatially averaged out by larger grid cell sizes.

\section{C2 Effects on spatially averaged emissions}

In the summer campaign, the differences between the measured emissions and the inventory emissions increases as the grid size increase (Table $\mathrm{C} 2$ ). The smallest difference is seen in the $50 \mathrm{~m}$ grid at $6.88 \mathrm{~kg} \mathrm{CO}_{2} \mathrm{ha}^{-1} \mathrm{~h}^{-1}$. In the winter campaign, the differences between the measured and inventory emissions are smallest in the $100 \mathrm{~m}\left(2.84 \mathrm{~kg} \mathrm{CO}_{2} \mathrm{ha}^{-1} \mathrm{~h}^{-1}\right)$ and $200 \mathrm{~m}\left(0.9 \mathrm{~kg} \mathrm{CO}_{2} \mathrm{ha}^{-1} \mathrm{~h}^{-1}\right)$ grid sizes and are greatest in the $50 \mathrm{~m}$ grid size at $7.8 \mathrm{~kg} \mathrm{CO}_{2} \mathrm{ha}^{-1} \mathrm{~h}^{-1}$.

In both campaigns, the spatial error (expressed RMSE) between measurements and inventory decreases as grid sizes become coarser. In the summer campaign, 80.05, 86.71, 85.31 , and $95.45 \%$ of the cells have measured emissions that are within a factor of \pm 10 of the total emissions inventory for the 50,100,200, and $400 \mathrm{~m}$ grids, respectively. In the winter campaign, 91.16, 93.74, 94.20, and $100 \%$ of the cells have measured emissions within \pm 10 of the total emissions inventory.
Table C1. Summary data of the measured mixing ratios for all grid sizes for the summer and winter campaigns. The table shows the mean, minimum, median, and maximum $\mathrm{CO}_{2}$ mixing ratio $r_{\text {mobile }}$ for the gridded data.

\begin{tabular}{lrrrr}
\hline Grid size & $\begin{array}{r}\text { Min } \\
(\mathrm{ppm})\end{array}$ & $\begin{array}{r}\text { Median } \\
(\mathrm{ppm})\end{array}$ & $\begin{array}{r}\text { Mean } \\
(\mathrm{ppm})\end{array}$ & $\begin{array}{r}\text { Max } \\
(\mathrm{ppm})\end{array}$ \\
\hline Summer & & & & \\
\hline $50 \mathrm{~m}$ & 393.1 & 409.4 & 417.3 & 529.8 \\
$100 \mathrm{~m}$ & 393.1 & 410.0 & 417.9 & 518.0 \\
$200 \mathrm{~m}$ & 397.0 & 412.9 & 419.6 & 488.2 \\
$400 \mathrm{~m}$ & 399.6 & 417.5 & 419.0 & 447.7 \\
\hline Winter & & & & \\
\hline $50 \mathrm{~m}$ & 408.4 & 434.5 & 442.6 & 643.1 \\
$100 \mathrm{~m}$ & 408.4 & 435.0 & 442.5 & 560.5 \\
$200 \mathrm{~m}$ & 408.4 & 436.8 & 443.7 & 529.4 \\
$400 \mathrm{~m}$ & 420.5 & 441.9 & 443.2 & 492.5 \\
\hline
\end{tabular}

For the winter campaign, we observe that the mean bias, i.e. differences between the mean measured emissions and the mean inventory emissions, decreases as grid size increases, presumably because more sampling points mean we average out random errors in individual cells. The best match is found at $200 \mathrm{~m}$ resolution. Of course, this is very sensitive to the calculated aerodynamic resistance and should not be interpreted as a generality.

For the summer campaign, however, there is an increasing difference between the mean measured emissions and the mean total emissions. This may be best explained by the bias towards roads in the sampling methodology. In the summer campaign, the dominant source are vehicles constrained to roads. The difference between the average measured emissions and the total emissions inventory is relatively small for the $50 \mathrm{~m}$ grid because the measurements are made mostly along roads and therefore do not include traffic-free areas such as in the backyards of homes and within large street blocks which can have significantly lower concentration of traffic-related pollutants (Weber and Weber, 2008). As a result, when comparing the average measured emissions to the average of the total emissions inventories for the 100, 200, and $400 \mathrm{~m}$ grids, we see that a sampling bias becomes more apparent. The $50 \mathrm{~m}$ grid cell size is a more appropriate resolution for gridding the point measurements collected using this methodology when traffic emissions dominate. Additional sampling along alleys and laneways and more representative sampling using alternative mobility options such as bicycles or drones may help to improve the relationship between measured emissions and the emissions inventory when gridding at coarser resolutions. 
Table C2. Mean measured emissions versus mean inventory emissions for the winter and summer campaigns.

\begin{tabular}{lrrrr}
\hline Grid size & $\begin{array}{r}\text { Measured emissions } \\
\left(\mathrm{kg} \mathrm{CO}_{2} \mathrm{ha}^{-1} \mathrm{~h}^{-1}\right)\end{array}$ & $\begin{array}{r}\text { Inventory emissions } \\
\left(\mathrm{kg} \mathrm{CO}_{2} \mathrm{ha}^{-1} \mathrm{~h}^{-1}\right)\end{array}$ & Relative difference & $\begin{array}{r}\text { RMSE } \\
\left(\mathrm{kg} \mathrm{CO}_{2} \mathrm{ha}^{-1} \mathrm{~h}^{-1}\right)\end{array}$ \\
\hline Summer & & & & \\
\hline $50 \mathrm{~m}$ & 34.06 & 27.18 & $+29 \%$ & 32.54 \\
$100 \mathrm{~m}$ & 35.11 & 22.06 & $+59 \%$ & 27.91 \\
$200 \mathrm{~m}$ & 38.30 & 19.73 & $+94 \%$ & 29.01 \\
$400 \mathrm{~m}$ & 37.26 & 15.27 & $+144 \%$ & \\
\hline Winter & & & & 34.57 \\
\hline $50 \mathrm{~m}$ & 25.67 & 33.47 & $-23 \%$ & 25.39 \\
$100 \mathrm{~m}$ & 25.92 & 28.76 & $-10 \%$ & 19.58 \\
$200 \mathrm{~m}$ & 27.21 & 26.31 & $+3 \%$ & 17.71 \\
$400 \mathrm{~m}$ & 26.60 & 23.33 & $+14 \%$ & \\
\hline
\end{tabular}


Competing interests. The authors declare that they have no conflict of interest.

Acknowledgements. This paper was supported through an NSERC Discovery Grant ("Direct measurement of greenhouse gas exchange in urban ecosystems", A. Christen). Sensor development and tower infrastructure were funded in part through the Canada Foundation for Innovation (grants 17141 and 33600). Scholarship to J. K. Lee was provided through NSERC CREATE and through the "Mozilla Science Lab". Experiment vehicles were sponsored by "moovel lab", Stuttgart, Germany. We thank A. Black, R. Kellett, S. Lapsky, and L. Lavkulich (all UBC) for their guidance, support, and help.

Edited by: G. Phillips

Reviewed by: E. Velasco and one anonymous referee

\section{References}

Arya, S. P.: Introduction to Micrometeorology, 2nd Edn., Vol. 39 of International Geophysics Series, Academic Press, San Diego, 2001.

Bjorkegren, A. B., Grimmond, C. S. B., Kotthaus, S., and Malamud, B. D.: $\mathrm{CO}_{2}$ emission estimation in the urban environment: Measurement of the $\mathrm{CO}_{2}$ storage term, Atmos. Environ., 122, 775-790, 2015.

Bukowiecki, N., Dommen, J., Prévôt, A. S. H., Richter, R., Weingartner, E., and Baltensperger, U.: A mobile pollutant measurement laboratory-measuring gas phase and aerosol ambient concentrations with high spatial and temporal resolution, Atmos. Environ., 36, 5569-5579, 2002.

Chapman, L., Young, D., Muller, C. L., Rose, P., Lucas, C., and Walden, J.: Winter Road Maintenance and the Internet of Things, in: Proceedings of the 17th International Road Weather Conference, 1-8, 2014.

Christen, A.: Atmospheric measurement techniques to quantify greenhouse gas emissions from cities, Urban Climate, 10, 241260, 2014.

Christen, A., van Gorsel, E., and Vogt, R.: Coherent structures in urban roughness sublayer turbulence, Int. J. Climatol., 27, 19551968, 2007.

Christen, A., Coops, N. C., Crawford, B. R., Kellett, R., Liss, K. N., Olchovski, I., Tooke, T. R., van der Laan, M., and Voogt, J. A.: Validation of modeled carbon-dioxide emissions from an urban neighborhood with direct eddy-covariance measurements, Atmos. Environ., 45, 6057-6069, 2011.

City of Vancouver: Open Data Catalogue - Directional volume traffic counts data, available at: http://data.vancouver.ca/ datacatalogue/trafficCounts.htm (last access: 15 June 2015), 2015.

Crawford, B. R. and Christen, A.: Spatial variability of carbon dioxide in the urban canopy layer and implications for flux measurements, Atmos. Environ., 98, 308-322, 2014.

Crawford, B. R. and Christen, A.: Spatial source attribution of measured urban eddy covariance $\mathrm{CO}_{2}$ fluxes, Theor. Appl. Climatol., 119, 1-23, 2015.
Elen, B., Peters, J., Poppel, M., Bleux, N., Theunis, J., Reggente, M., and Standaert, A.: The Aeroflex: A Bicycle for Mobile Air Quality Measurements, Sensors, 13, 221-240, 2013.

British Columbia Ministry of Transportation: 2014 B.C. Best Practices Methodology for Quantifying Greenhouse Gas Emissions, Tech. rep., Victoria, BC, Canada, 2014.

FLUXNET: Integrating Worldwide $\mathrm{CO}_{2}$, water, and energy flux measurements, available at: http://fluxnet.ornl.gov/site/4132 (last access: 20 February 2017), 2016.

Grimmond, C. S. B., King, T., Cropley, F., Nowak, D. J., and Souch, C.: Local-scale fluxes of carbon dioxide in urban environments: methodological challenges and results from Chicago, Environ. Pollut., 116, S243-S254, 2002.

Grimmond, S.: Urbanization and global environmental change: local effects of urban warming, Geogr. J., 173, 83-88, 2007.

Henninger, S. and Kuttler, W.: Methodology for mobile measurements of carbon dioxide within the urban canopy layer, Clim. Res., 34, 161-167, 2007.

Holleczek, T., Yu, L., Lee, J. K., Senn, O., Ratti, C., and Jaillet, P.: Detecting weak public transport connections from cellphone and public transport data, in: the 2014 International Conference, 1-8, ACM Press, New York, New York, USA, 2014.

Humphreys, E. R., Black, T. A., Morgenstern, K., Cai, T., Drewitt, G. B., Nesic, Z., and Trofymow, J. A.: Carbon dioxide fluxes in coastal Douglas-fir stands at different stages of development after clearcut harvesting, Agr. Forest Meteorol., 140, 6-22, 2006.

Idso, C., Idso, S., and Balling, R.: An intensive two-week study of an urban $\mathrm{CO}_{2}$ dome in Phoenix, Arizona, USA, Atmos. Environ., 35, 995-1000, 2001.

IPCC: Climate Change 2013: The Physical Science Basis, Contribution of Working Group I to the Fifth Assessment Report of the Intergovernmental Panel on Climate Change, edited by: Stocker, T. F., Qin, D., Plattner, G.-K., Tignor, M., Allen, S. K., Boschung, J., Nauels, A., Xia, Y., Bex, V., and Midgley, P. M., Cambridge University Press, 2013.

IPCC: Climate Change Impacts, Adaptation, and Vulnerability: Contribution of Working Group IV to the Fifth Assessment Report of the Intergovernmental Panel on Climate Change, Cambridge University Press, 2014.

Jimenez, J. L., McManus, J. B., Shorter, J. H., Nelson, D. D., Zahniser, M. S., Koplow, M., McRae, G. J., and Kolb, C. E.: Cross road and mobile tunable infrared laser measurements of nitrous oxide emissions from motor vehicles, Chemosphere - Global Change Science, 2, 397-412, Elsevier, 2000.

Jin, S., Guo, J., Wheeler, S., Kan, L., and Che, S.: Evaluation of impacts of trees on $\mathrm{PM}_{2.5}$ dispersion in urban streets, Atmos. Environ., 99, 277-287, 2014.

Kanda, M., Kanega, M., Kawai, T., Moriwaki, R., and Sugawara, H.: Roughness Lengths for Momentum and Heat Derived from Outdoor Urban Scale Models, J. Appl. Meteorol. Clim., 46, 1067-1079, 2007.

Kellett, R., Christen, A., Coops, N. C., van der Laan, M., Crawford, B., Tooke, T. R., and Olchovski, I.: A systems approach to carbon cycling and emissions modelling at an urban neighbourhood scale, Landscape Urban Plan., 110, 48-58, 2013.

Kennedy, C., Steinberger, J., Gasson, B., Hansen, Y., Hillman, T., Havránek, M., Pataki, D., Phdungsilp, A., Ramaswami, A., and Mendez, G. V.: Greenhouse Gas Emissions from Global Cities, Environ. Sci. Technol., 43, 7297-7302, 2009. 
Lee, J., Christen, A., Ketler, R., and Nesic, Z.: Mobile measurements of carbon dioxide mixing ratios and emissions in the City of Vancouver, BC, Canada, doi:10.1594/PANGAEA.872702, 2017.

Li-Cor: Advantages of the LI-820, available at: https://www.licor. com/env/products/gas_analysis/LI-820/ (last access: 20 February 2017), 2015.

Martani, C., Lee, D., Robinson, P., Britter, R., and Ratti, C.: ENERNET: Studying the dynamic relationship between building occupancy and energy consumption, Energ. Buildings, 47, 584-591, 2012.

Meier, F., Fenner, D., Grassmann, T., Otto, M., and Scherer, D.: Crowdsourcing air temperature from citizen weather stations for urban climate research, Urban Climate, doi:10.1016/j.uclim.2017.01.006, in press, 2017.

Micrometerology Group: The DIYSCO 2 Project, available at: https: //diysco2.github.io/, last access: 23 February 2017.

Mills, G.: Cities as agents of global change, Int. J. Climatol., 27, 1849-1857, 2007.

Moosavi, V., Aschwanden, G., and Velasco, E.: Finding candidate locations for aerosol pollution monitoring at street level using a data-driven methodology, Atmos. Meas. Tech., 8, 3563-3575, doi:10.5194/amt-8-3563-2015, 2015.

Natural Resources Canada: 2014 Fuel Consumption Guide, 1-11, Government of Canada, Natural Resources Canada, 2014.

Newman, S., Jeong, S., Fischer, M. L., Xu, X., Haman, C. L., Lefer, B., Alvarez, S., Rappenglueck, B., Kort, E. A., Andrews, A. E., Peischl, J., Gurney, K. R., Miller, C. E., and Yung, Y. L.: Diurnal tracking of anthropogenic $\mathrm{CO}_{2}$ emissions in the Los Angeles basin megacity during spring 2010, Atmos. Chem. Phys., 13, 4359-4372, doi:10.5194/acp-13-4359-2013, 2013.

Pataki, D., Emmi, P., Forster, C., Mills, J., Pardyjak, E., Peterson, T., Thompson, J., and Dudley-Murphy, E.: An integrated approach to improving fossil fuel emissions scenarios with urban ecosystem studies, Ecol. Complex., 6, 1-14, 2009.

Peters, E. B. and McFadden, J. P.: Continuous measurements of net $\mathrm{CO}_{2}$ exchange by vegetation and soils in a suburban landscape, J. Geophys. Res.-Atmos., 117, G03005, doi:10.1029/2011JG001933, 2012.
Rosenzweig, C., Solecki, W., and Hammer, S. A.: Cities lead the way in climate-change action, Nature, 467, 909-911, doi:10.1038/467909a, 2010.

Salmond, J. A., Oke, T. R., Grimmond, C. S. B., Roberts, S. M., and Offerle, B. D.: Venting of heat and carbon dioxide from urban canyons at night, J. Appl. Meteorol., 44, 1180-1193, 2005.

Satterthwaite, D.: Cities' contribution to global warming: notes on the allocation of greenhouse gas emissions, Environ. Urban., 20, 539-549, 2008.

Stewart, I. D. and Oke, T. R.: Local Climate Zones for Urban Temperature Studies, B. Am. Meteorol. Soc., 93, 1879-1900, 2012.

Tao, L., Sun, K., Miller, D. J., Pan, D., Golston, L. M., and Zondlo, M. A.: Low-power, open-path mobile sensing platform for highresolution measurements of greenhouse gases and air pollutants, Appl. Phys. B, 119, 153-164, 2015.

United Nations: The World Population Situation in 2014 - A concise report, 1-38, United Nations, Department of Economic and Social A airs, Population Division, New York, 2014.

van der Laan, M.: Scaling Urban Energy Use and Greenhouse Gas Emissions through LiDAR, Master's thesis, The University of British Columbia, 2011.

Velasco, E., Roth, M., Norford, L., and Molina, L. T.: Does urban vegetation enhance carbon sequestration?, Landscape Urban Plan., 148, 99-107, 2016.

Vogt, R., Christen, A., Rotach, M. W., Roth, M., and Satyanarayana, A. N. V.: Temporal dynamics of $\mathrm{CO}_{2}$ fluxes and profiles over a central European city, Theor. Appl. Climatol., 84, 117-126, 2006.

Weber, S. and Weber, K.: Coupling of urban street canyon and backyard particle concentrations, Meteorol. Z., 17, 251-261, 2008.

Weissert, L. F., Salmond, J. A., and Schwendenmann, L.: A review of the current progress in quantifying the potential of urban forests to mitigate urban $\mathrm{CO}_{2}$ emissions, Urban Climate, 8 , 100-125, 2014. 